Prepared in cooperation with the Minnesota Department of Transportation

Water- and Bed-Sediment Quality of Seguchie Creek and Selected Wetlands Tributary to Mille Lacs Lake in Crow Wing County, Minnesota, October 2003 to October 2006

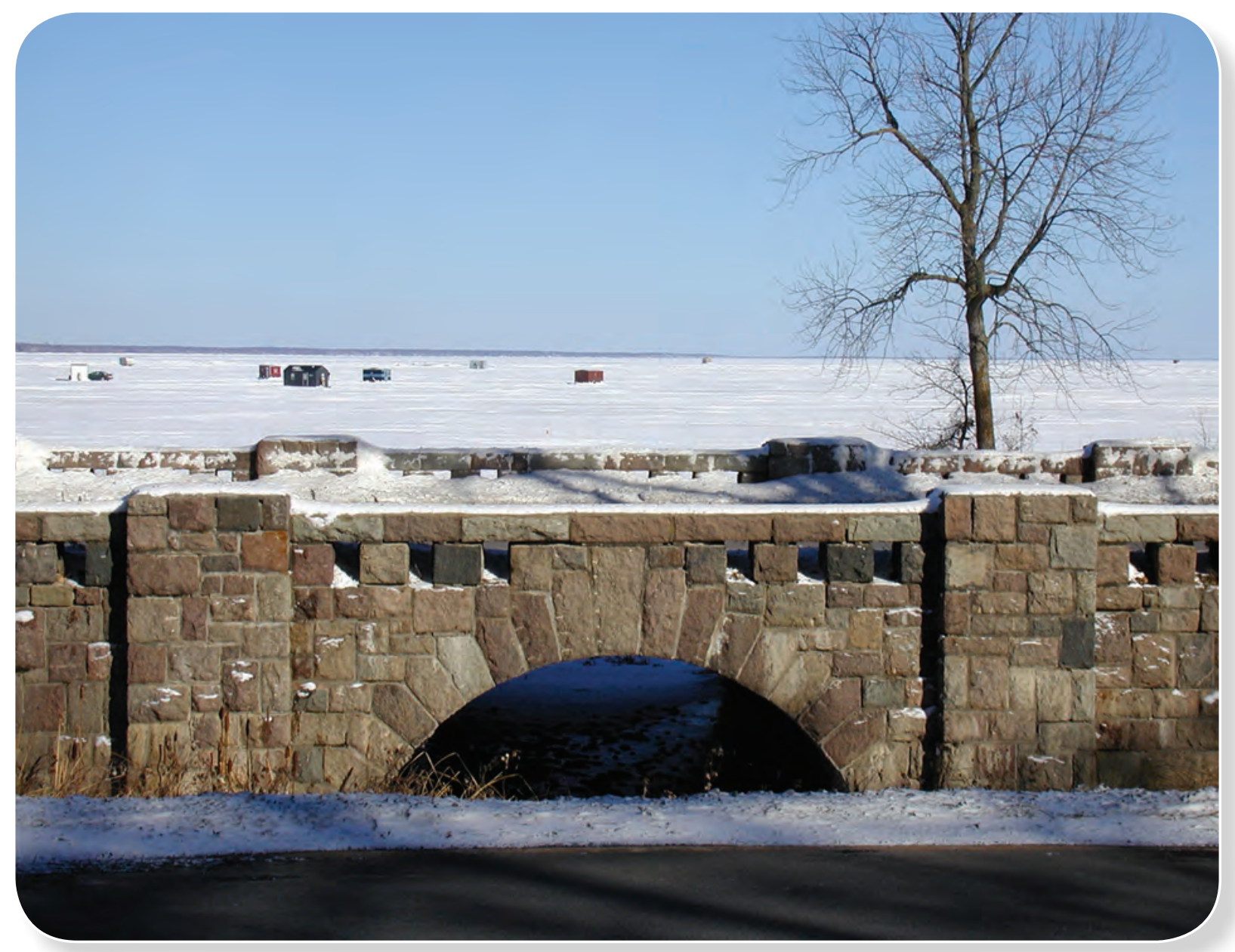

Scientific Investigations Report 2009-5218 
Cover photograph: Bridge 5265 on U.S. Highway 169, built by the Civilian Conservation Corps in 1938 and listed on the National Register of Historic Places, spans an unnamed tributary that flows to Mille Lacs Lake and ice-fishing houses near Garrison, Minnesota. 


\section{Water- and Bed-Sediment Quality of Seguchie Creek and Selected Wetlands Tributary to Mille Lacs Lake in Crow Wing County, Minnesota, October 2003 to October 2006}

By James D. Fallon and Christine S. Yaeger

Prepared in cooperation with the Minnesota Department of Transportation

Scientific Investigations Report 2009-5218 


\section{U.S. Department of the Interior \\ KEN SALAZAR, Secretary}

\section{U.S. Geological Survey \\ Marcia K. McNutt, Director}

U.S. Geological Survey, Reston, Virginia: 2009

For more information on the USGS — the Federal source for science about the Earth, its natural and living resources, natural hazards, and the environment, visit http://www.usgs.gov or call 1-888-ASK-USGS

For an overview of USGS information products, including maps, imagery, and publications, visit http://www.usgs.gov/pubprod

To order this and other USGS information products, visit http://store.usgs.gov

Any use of trade, product, or firm names is for descriptive purposes only and does not imply endorsement by the U.S. Government.

Although this report is in the public domain, permission must be secured from the individual copyright owners to reproduce any copyrighted materials contained within this report.

Suggested citation:

Fallon, J.D., and Yaeger, C.S., 2009, Water- and bed-sediment quality of Seguchie Creek and selected wetlands tributary to Mille Lacs Lake in Crow Wing County, Minnesota, October 2003 to October 2006: U.S. Geological Survey Scientific Investigations Report 2009-5218, 39 p. 


\section{Contents}

Abstract

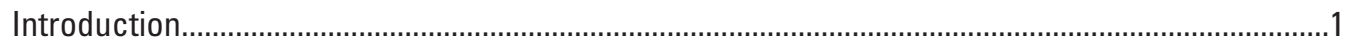

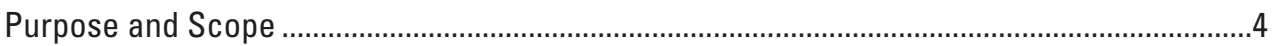

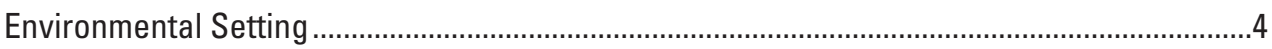

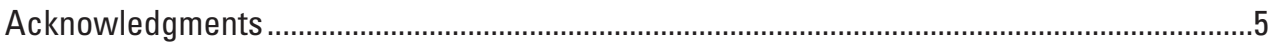

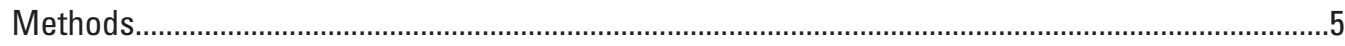

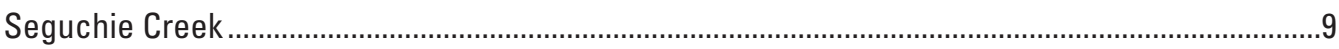

Streamflow

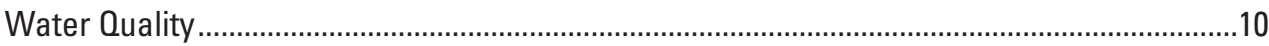

Concentrations and Physical Properties .........................................................................10

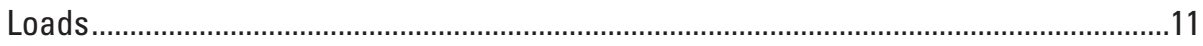

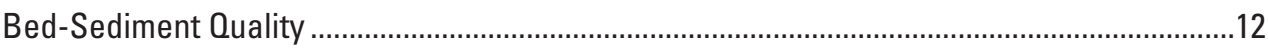

Size

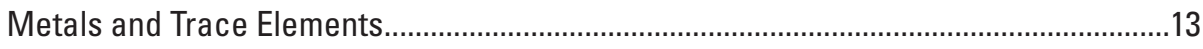

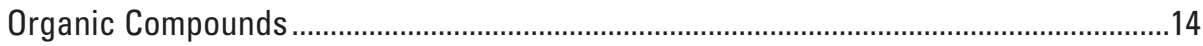

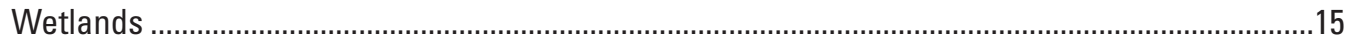

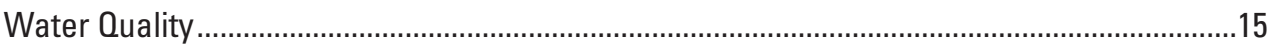

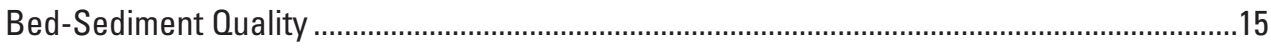

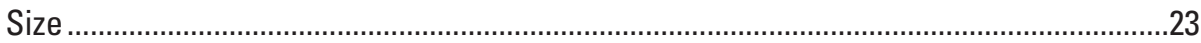

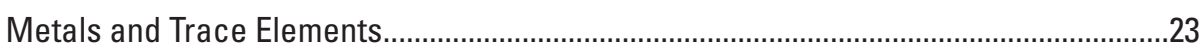

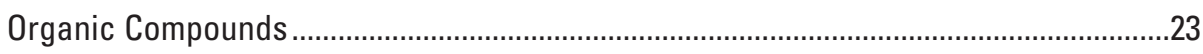

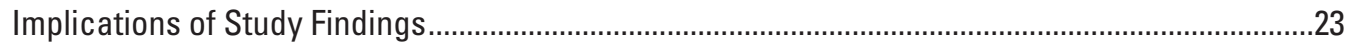

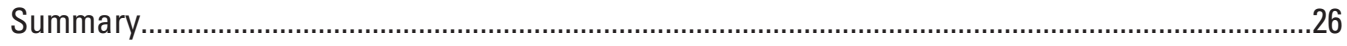

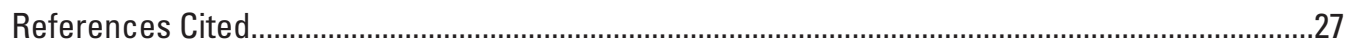

\section{Figures}

1. Map showing study area and sampling locations for Seguchie Creek and wetlands 9, 15,

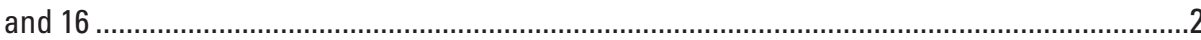

2. Daily-mean streamflow and specific conductance at upstream and downstream gaging stations on Seguchie Creek near Garrison, Minnesota................................................10

3. Photographs showing bed-sediment samples collected from (A) Seguchie Creek for particle size analysis, $(B)$ wetland 16 for particle size and chemical analyses, and $(C)$ wetland 15 for particle size and chemical analyses....................................................12

4. Graph showing particle-size distribution of bed sediment in upstream and downstream Seguchie Creek sites and wetlands, near Garrison, Minnesota, October 2003 to October 2006

\section{Tables}

1. Types and frequencies of measurements and samples collected.......................................7

2. Summary statistics of streamflow and water-quality data for Seguchie Creek, 2003-06......32 
3. Summary statistics of selected water-quality data from Seguchie Creek above mouth near Garrison, Minnesota, (station 05284310) upstream and downstream from reach with

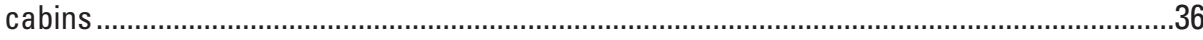

4. Equation coefficients and associated statistics used to calculate loads ............................13

5. Estimated loading rates for dissolved chloride, selected nutrients, and suspended sediment

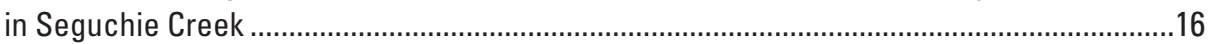

6. Concentrations of metals and trace elements in bed-sediment samples at Seguchie Creek sites and wetlands 9, 15, and 16 in Minnesota, October 2003 to September 2005

7. Concentrations of semivolatile organic compounds in bed-sediment samples from Seguchie Creek sites and wetlands 9, 15, and 16 in Minnesota, October 2003 to September 2005.

8. Water-quality data from wetlands 9, 15, and 16, near Garrison, Minnesota 


\section{Conversion Factors, Abbreviations, and Datums}

\begin{tabular}{|c|c|c|}
\hline Multiply & By & To obtain \\
\hline \multicolumn{3}{|c|}{ Length } \\
\hline centimeter $(\mathrm{cm})$ & 0.3937 & inch (in.) \\
\hline millimeter (mm) & 0.03937 & inch (in.) \\
\hline meter $(\mathrm{m})$ & 3.281 & foot $(\mathrm{ft})$ \\
\hline kilometer $(\mathrm{km})$ & 0.6214 & mile (mi) \\
\hline \multicolumn{3}{|c|}{ Area } \\
\hline square meter $\left(\mathrm{m}^{2}\right)$ & 10.76 & square foot $\left(\mathrm{ft}^{2}\right)$ \\
\hline square kilometer $\left(\mathrm{km}^{2}\right)$ & 0.3861 & square mile $\left(\mathrm{mi}^{2}\right)$ \\
\hline \multicolumn{3}{|c|}{ Volume } \\
\hline liter (L) & 0.2642 & gallon (gal) \\
\hline cubic meter $\left(\mathrm{m}^{3}\right)$ & 35.31 & cubic foot $\left(\mathrm{ft}^{3}\right)$ \\
\hline cubic hectometer $\left(\mathrm{hm}^{3}\right)$ & 810.7 & acre-foot (acre-ft) \\
\hline \multicolumn{3}{|c|}{ Flow rate } \\
\hline liter per second(L/s) & 15.85 & gallon per minute (gal/min) \\
\hline cubic hectometer per year $\left(\mathrm{hm}^{3} / \mathrm{yr}\right)$ & 810.7 & acre-foot per year (acre-ft/yr) \\
\hline cubic meter per second $\left(\mathrm{m}^{3} / \mathrm{s}\right)$ & 35.31 & cubic foot per second $\left(\mathrm{ft}^{3} / \mathrm{s}\right)$ \\
\hline \multicolumn{3}{|c|}{ Mass } \\
\hline gram $(\mathrm{g})$ & 0.03527 & ounce, avoirdupois (oz) \\
\hline kilogram (kg) & 2.205 & pound avoirdupois (lb) \\
\hline
\end{tabular}

Temperature in degrees Celsius $\left({ }^{\circ} \mathrm{C}\right)$ may be converted to degrees Fahrenheit $\left({ }^{\circ} \mathrm{F}\right)$ as follows:

$$
{ }^{\circ} \mathrm{F}=\left(1.8 \times^{\circ} \mathrm{C}\right)+32
$$

Vertical coordinate information is referenced to the North American Vertical Datum of 1929 (NAVD 29).

Horizontal coordinate information is referenced to the North American Datum of 1983 (NAD83).

Specific conductance is given in microsiemens per centimeter at 25 degrees Celsius $(\mu \mathrm{S} / \mathrm{cm}$ at $25^{\circ} \mathrm{C}$ ).

Concentrations of chemical constituents in water are given in milligrams per liter ( $\mathrm{mg} / \mathrm{L})$ or micrograms per liter $(\mu \mathrm{g} / \mathrm{L})$. Concentrations of chemical constituents in bed sediment are given in micrograms per gram $(\mu \mathrm{g} / \mathrm{g})$ or micrograms per kilogram $(\mu \mathrm{g} / \mathrm{kg})$. 


\section{Acronyms and Other Abbreviations Used in Report}

$\begin{array}{ll}< & \text { less than } \\ \mathrm{mg} / \mathrm{L} & \text { milligrams per liter } \\ \mu \mathrm{g} / \mathrm{L} & \text { micrograms per liter } \\ \mu \mathrm{g} / \mathrm{g} & \text { micrograms per gram } \\ \mu \mathrm{g} / \mathrm{kg} & \text { micrograms per kilogram } \\ \mu \mathrm{S} / \mathrm{cm} & \text { microsiemens per centimeter } \\ \text { AMLE } & \text { adjusted maximum likelihood estimate } \\ \text { BMP } & \text { best management practice } \\ \text { CCME } & \text { Canadian Council of Ministers of the Environment } \\ \text { EWI } & \text { equal-width increment } \\ \text { ISQG } & \text { Interim Sediment Quality Guideline } \\ \text { LAD } & \text { least absolute deviation } \\ \text { LTMDL } & \text { long-term method detection level } \\ \text { MNDOT } & \text { Minnesota Department of Transportation } \\ \text { MRL } & \text { minimum reporting level } \\ \text { PAH } & \text { polycyclic aromatic hydrocarbon } \\ \text { PEL } & \text { Probable Effects Level } \\ \text { USEPA } & \text { U.S. Environmental Protection Agency } \\ \text { USGS } & \text { U.S. Geological Survey }\end{array}$




\title{
Water- and Bed-Sediment Quality of Seguchie Creek and Selected Wetlands Tributary to Mille Lacs Lake in Crow Wing County, Minnesota, October 2003 to October 2006
}

\author{
By James D. Fallon and Christine S. Yaeger
}

\section{Abstract}

Mille Lacs Lake and its tributaries, located in east-central Minnesota, are important resources to the public. In addition, many wetlands and lakes that feed Mille Lacs Lake are of high resource quality and vulnerable to degradation. Construction of a new four-lane expansion of U.S. Highway 169 has been planned along the western part of the drainage area of Mille Lacs Lake in Crow Wing County. Concerns exist that the proposed highway could affect the resource quality of surface waters tributary to Mille Lacs Lake. Baseline water- and bedsediment quality characteristics of surface waters tributary to Mille Lacs Lake were needed prior to the proposed highway construction. The U.S. Geological Survey, in cooperation with the Minnesota Department of Transportation, characterized the water- and bed-sediment quality at selected locations that the proposed route intersects from October 2003 to October 2006. Locations included Seguchie Creek upstream and downstream from the proposed route and three wetlands draining to Mille Lacs Lake.

The mean streamflow of Seguchie Creek increased between the two sites: flow at the downstream streamflowgaging station of 0.22 cubic meter per second was 5.6 percent greater than the mean streamflow at the upstream streamflowgaging station of 0.21 cubic meter per second. Because of the large amount of storage immediately upstream from both gaging stations, increases in flow were gradual even during intense precipitation.

The ranges of most constituent concentrations in water were nearly identical between the two sampling sites on Seguchie Creek. No concentrations exceeded applicable waterquality standards set by the State of Minnesota. Dissolvedoxygen concentrations at the downstream gaging station were less than the daily minimum standard of 4.0 milligrams per liter for 6 of 26 measurements.

Constituent loads in Seguchie Creek were greater at the downstream site than the upstream site for all measured, including dissolved chloride (1.7 percent), ammonia plus organic nitrogen (13 percent), total phosphorus (62 percent), and suspended sediment (11 percent) during the study. All constituents had seasonal peaks in spring and fall. The large loads during the fall resulted from unusually large precipitation and streamflow patterns. This caused the two greatest streamflow peaks at both sites to occur during October (2004 and 2005).

In Seguchie Creek, bed-sediment concentrations of five metals and trace elements (arsenic, cadmium, chromium, lead, and zinc) exceeded the Interim Sediment Quality Guidelines (ISQG) set by the Canadian Council of Ministers of the Environment. Bed-sediment samples from the upstream site had more exceedances of ISQGs for metals and trace elements than did samples from the downstream site (seven and two exceedances, respectively). Bed-sediment samples from the downstream site had more exceedances of ISQGs (20 exceedances) for semivolatile organic compounds than did samples from the upstream site ( 8 exceedances), indicating different sources for organic compounds than for metals and trace elements. Concentrations of 11 semivolatile organic compounds exceeded ISQGs: ancenaphthene, acenaphthylene, anthracene, benzo $[a]$ anthracene, benzo $[a]$ pyrene, chrysene, fluoranthene, fluorene, naphthalene, phenanthrene, and pyrene.

In bed-sediment samples collected from three wetlands, concentrations of all six metals exceeded ISQGs: arsenic, cadmium, chromium, copper, lead, and zinc. Concentrations of three semivolatile organic compounds exceeded ISQGs: flouranthene, phenanthrene, and pyrene. Results indicate that areas appearing relatively undisturbed and of high resource value can have degraded quality from previous unknown land use.

\section{Introduction}

Mille Lacs Lake and its tributaries, located in east-central Minnesota (fig. 1), are important resources to the public. Mille Lacs Lake is the second largest inland lake in Minnesota by surface area (534 square kilometers $\left(\mathrm{km}^{2}\right)$; Minnesota Department of Natural Resources, 2006). It is a popular recreation area known for its exceptional game fisheries and water quality and an important resource for the Ojibwe Bands. The Ojibwe people, composed of the Mille Lacs, Fond du Lac, and six other Bands, have treaty protected fishing rights in Mille Lacs Lake (Great Lakes Indian Fish and Wildlife Commission, 2004). Although large in surface area, Mille Lacs Lake is sensitive to eutrophication from increased nutrient loads (Heiskary and others, 1994) because of its relatively shallow 


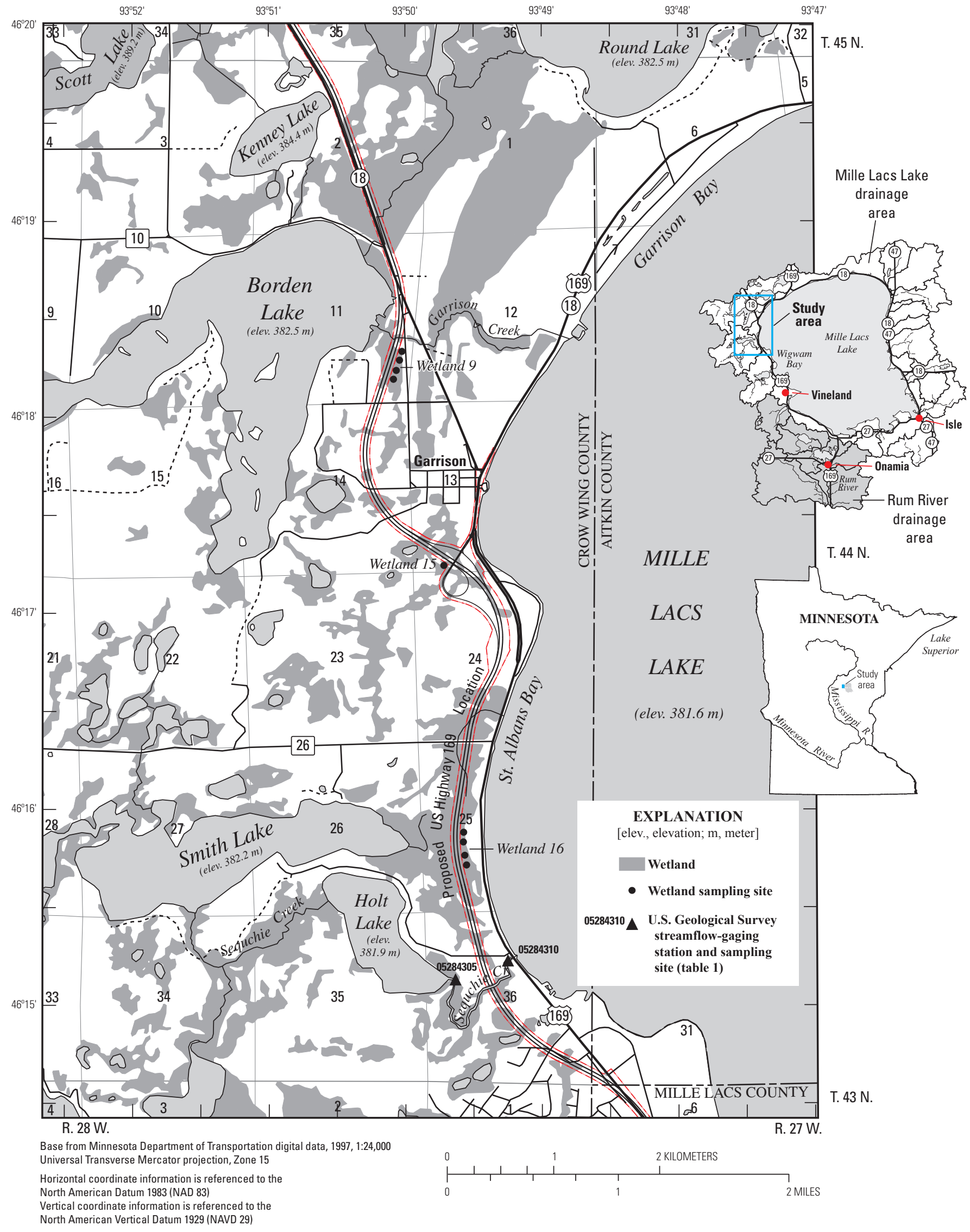

Figure 1. Study area and sampling locations for Seguchie Creek and wetlands 9, 15, and 16. 
depth (maximum depth of approximately 12.2 meters (m); Minnesota Department of Natural Resources, 2006).

In addition to the resource value of Mille Lacs Lake, many wetlands and smaller lakes that feed the lake are of high resource quality and vulnerable to degradation. Many wetlands support wild rice beds, feed streams and lakes, and provide habitat for keystone wildlife species - species integral to the health and structure of other species (Minnesota Department of Transportation, 2002). Smaller tributary lakes are popular fisheries and recreation areas, and sustain streams draining to Mille Lacs Lake.

Construction of a new four-lane expansion of U.S. Highway 169 has been planned by the Minnesota Department of Transportation (MNDOT) along the western part of the drainage area of Mille Lacs Lake in Crow Wing County. Several highway alignments are under consideration in the southwestern part of this area, but alignment is more certain in the northwestern part of this area (James Hallgren, Minnesota Department of Transportation, oral commun., 2003). This proposed highway could affect the quality of water resources tributary to Mille Lacs Lake, and the lake itself, because potential routes pass through a substantial portion of the relatively small drainage area $\left(1,067 \mathrm{~km}^{2}\right)$ of the lake.

Degradation of the quality of natural waters can result from highway construction activities, subsequent operation and maintenance, and changes in land use associated with increased human activities or development near highways. Highway construction activities can degrade surface water if runoff from disturbed and exposed soils increases erosion and concentrations of suspended sediment, phosphorus (Bricker, 1999), and other contaminants attached to soil particles. Suspended sediment, nutrients, and salts occur at low concentrations in natural waters near the study area (Fallon and McNellis, 2000; Kroening and others, 2003; Stark and others, 1996).

Highway operation and maintenance activities can degrade water quality through contributions of suspended sediment, deicing chemicals (chloride, sodium, and sulfate), nutrients, metals, and organic compounds (Bricker, 1999; Legret and Pagotto, 1999). These constituents can enter surface water from spills on the highway surface; erosion of the shoulders, medians, and ditches; and atmospheric deposition of particulate matter and road spray drift. Salt-based deicing chemicals are chemically conservative and can be transported to receiving waters through direct runoff and road spray. Salt-based deicers commonly contain additional constituents, including sulfate, which has been shown to be the largest contaminant of road salt by mass (Granato and Smith, 1999). Sulfate can contribute to lake eutrophication by freeing phosphorus otherwise bound to sediments (Lamers and others, 2002). Soluble constituents such as chloride and nitrate nitrogen may infiltrate to groundwater from swales and retention basins designed to store and filter highway runoff. Once in groundwater, these constituents can eventually discharge to streams, wetlands, lakes, or drinking-water wells. Metals from automobiles and chemicals applied to, or spilled on, roadways and easements can leach into water or be adsorbed to sediments. Organic compounds, including polycyclic aromatic hydrocarbons (PAHs), phthalates and phenols, can run off from roadway spills and drips or be deposited atmospherically from vehicle emissions and dust particles (Gjessing and others, 1984). These compounds generally are hydrophobic, so sediment concentrations generally are greater than dissolved concentrations in water (Lyman and others, 1987).

Development of lands adjacent to new highways can add to the quantities and types of constituents previously described. Feeder roadways add impervious surfaces and traffic volume. Areas of land disturbance near highways increase. Activities in developed areas can increase constituent loading rates to streams through point- and nonpoint-source runoff. In the Upper Mississippi River Basin, metals and organic compounds in streambed sediment were found in the greatest concentrations within and downstream from urban areas, compared to forest or agricultural areas (Kroening and others, 2000; McNellis and others, 2001).

Some constituents can have adverse effects on environmental or human health when present in large enough concentrations in water or bed sediment. Suspended sediment can affect aquatic habitats and commonly carries phosphorus, metals, and organic compounds (Lyman and others, 1987). Phosphorus and nitrogen contribute to eutrophication, algal blooms, and variability in dissolved-oxygen concentrations that can be harmful to fish and other aquatic organisms (Wetzel, 2001). Elevated concentrations of chloride are harmful to aquatic organisms (Short and others, 1991). Aquatic and human-health concerns have led to the creation of guidelines for maximum concentrations of many of these compounds in the environment.

To minimize the potential degradation of the quality of water bodies adjacent to the proposed highway and to Mille Lacs Lake, the MNDOT plans for the new highway route to be located farther from Mille Lacs Lake than the current route, and for new best management practices (BMPs) to be used that minimize highway runoff (Curt Eastlund, Minnesota Department of Transportation, written commun., 2003). Swales placed in the medians will be designed to capture, retain, and infiltrate highway runoff rather than allowing it to pass directly to receiving water bodies. These plans require the route to pass through areas that are relatively undisturbed (fig. 1).

To assess the potential eutrophication of Mille Lacs Lake and minimize the contributions resulting from highway and land-use development, the MNDOT hired a consultant to develop a model to simulate water and nutrient budgets for tributaries to the lake (Curt Eastlund, Minnesota Department of Transportation, written commun., 2003). The 2001 model was used to estimate nutrient and other constituent loading rates for existing land-use conditions, varying highway routes, varying annual precipitation amounts for wet, normal, and dry years, use of different BMPs for the highway, and increased land-use development. The model was calibrated with data from 2000. Estimated annual phosphorus concentrations ranged from 0.046 to 0.052 milligram per liter $(\mathrm{mg} / \mathrm{L})$ 
Water- and Bed-Sediment Quality of Seguchie Creek and Selected Wetlands Tributary to Mille Lacs Lake

for undeveloped conditions and from 0.055 to $0.063 \mathrm{mg} / \mathrm{L}$ for existing (1992-2000) land-use conditions and typical precipitation.

Baseline water- and bed-sediment-quality characteristics of surface waters tributary to Mille Lacs Lake prior to the proposed highway construction (fig. 1) were needed to determine the effects (if any) of highway construction, operation, and subsequent land-use changes on the quality of these waters. The U.S. Geological Survey (USGS), in cooperation with the MNDOT, characterized the water- and bed-sediment quality from October 2003 to October 2006 for Seguchie Creek upstream and downstream from the proposed route and for three wetlands draining to Mille Lacs Lake that the proposed route intersects.

Few studies are able to conduct sampling and collect data prior to activities that can affect water quality. As part of this study, two locations on Seguchie Creek upstream and downstream from the planned highway were (1) continuously monitored for streamflow, water temperature, specific conductance, and rainfall; (2) intermittently sampled for major ions, nutrients, metals, trace elements, and suspended sediment in water; and (3) intermittently sampled for particle-size distribution, metals, trace elements, and semivolatile organic compounds in bed sediment. Three wetlands were sampled annually for nutrients in water and particle-size distribution, metals, trace elements, and semivolatile organic compounds in bed sediment. Because much of the study area was assumed to be relatively undisturbed prior to proposed construction, data collected can be used as baseline information to determine the effects of highways and changes in land use on water quality. Water-quality data collected prior to construction can be compared with data from future studies to evaluate the effectiveness of newer construction BMPs designed to minimize effects of highway runoff. Data collected during this study also add to a national database on the effects of highways on the water quality of runoff and can be used to assess the effects of associated changes in land use on water quality. Results have transferability to much of the northern United States, where other post-glaciated landscapes are experiencing population growth and development. The data collected can provide an enhanced understanding of the effects of highway construction and operation on streams, wetlands, and lakes in northern climates.

The vulnerability of groundwater resources also is a concern where the proposed highway route overlies recharge areas. The Mille Lacs Lake consolidated drift aquifer, which approximately underlies the drainage area of Mille Lacs Lake, is a sole source aquifer that provides the majority of the drinking water for people in the area (Trotta and Cowdery, 1998). One well near Vineland, located $6 \mathrm{~km}$ south of the study area, provides the Mille Lacs Band of Ojibwe with much of their drinking water. Most of the interaction between surface water and groundwater occurs in the southwestern part of the Mille Lacs Lake drainage area (Trotta and Cowdery, 1998), so groundwater was not characterized as part of this study, which focuses on the northwestern part of the drainage area.

\section{Purpose and Scope}

The purpose of this report is to describe the water- and bed-sediment quality of Seguchie Creek and three selected wetlands tributary to Mille Lacs Lake, Minnesota, with respect to constituents commonly associated with highway construction and operation. The report provides baseline water-quality data prior to the proposed highway construction.

This report presents water- and bed-sediment-quality characteristics of selected relatively undisturbed watersheds that intersect the proposed route for expanded U.S. Highway 169 on the northwestern side of Mille Lacs Lake, Crow Wing County, Minnesota. In addition to consideration of resource quality, stream sites were selected to optimize the accuracy of streamflow and constituent loadings for streams. The wetlands sampled were identified as high-resource quality, are intersected by the planned highway route, and are adjacent to future highway construction that utilizes new BMPs. The study includes more than 3 years (October 2003 to October 2006) of pre-construction sampling. Implications of the study findings also are presented.

Original investigation objectives included a comparison of baseline (preconstruction) water-quality conditions with those observed during and after highway construction. However, at the time of report preparation (2008), highway construction had been delayed indefinitely. Consequently, documenting changes in water-quality conditions because of construction and highway operation is beyond the scope of this report. Because the proposed highway route has not been determined through the southeastern part of drainage area of Mille Lacs Lake, which contains most of the aquifer and groundwater resources of concern, analysis of groundwater is beyond the scope of this report.

\section{Environmental Setting}

The proposed highway route and study area are located in the western part of the drainage area of Mille Lacs Lake near Garrison in Crow Wing County, Minnesota (fig. 1). Along the western side of Mille Lacs Lake, the northern part contains more drainage area to Mille Lacs Lake than the southern part. Surface water in the southern part mostly flows to the Rum River - the outflow from Mille Lacs Lake (fig. 1). Consequently, highway construction in the southern part poses less concern for lake degradation, but may be more vulnerable to groundwater degradation (Trotta and Cowdery, 1998) than the northern part.

The ecosystems, surficial geology, and climate have been summarized by the U.S. Department of Agriculture (Albert, 1995). Briefly, Mille Lacs Lake and its drainage area are located in east-central Minnesota in the Mille Lacs Uplands of the Northern Minnesota Ecosystem and at the southern end of the Northern Lakes and Forest Ecoregion. Land forms are heterogeneous because of interaction from the Superior and Des Moines Lobe glaciations. Topography on the western side 
of Mille Lacs Lake is composed of rolling irregular hills, interspersed with kettle lakes, peatlands, and wetlands associated with end-moraines from the Superior Lobe glaciation. Soils also are heterogeneous. Acidic or calcareous soils are most common, derived from silt and clay-rich glacial drift and interspersed with sand or gravel, depending on the parent material. Vegetation commonly consists of mixed hardwood, pine, and aspen-birch forests in uplands, and of conifer swamps and bogs in lowlands. In the lowlands where Seguchie Creek and the monitored wetlands are located, high-quality plant communities can include black ash swamp, forested bogs, poor fens, tamarack swamps, and wet meadows. Rare plants can include American water-pennywort, bog bluegrass, halberd-leaved tearthumb, and eastern hemlock.

Wetlands in the vicinity of possible highway routes were inventoried and assessed in a supplemental study of wetland features (Minnesota Department of Transportation, 2002; Curt Eastlund, Minnesota Department of Transportation, written commun., 2003). Minnesota generally follows the U.S. Fish and Wildlife Service wetland classification system (Cowardin and others, 1979) that includes eight types: (1) seasonally flooded basins or flats, (2) wet meadows, (3) shallow marshes, (4) deep marshes, (5) shallow open water, (6) shrub swamps, (7) wooded swamps, and (8) bogs (Minnesota Department of Natural Resources, 2007). Proposed highway routes intersect all eight types of wetlands. Functional values of these wetlands were rated for floral diversity and integrity, maintenance of hydrologic regime, stormwater attenuation, water-quality protection, shoreline protection, groundwater interaction, wildlife habitat, fishery habitat, aesthetic or recreational or cultural value, and commercial uses (Curt Eastlund, Minnesota Department of Transportation, written commun., 2003). Wetlands identified as having been minimally affected by past human activities or with exceptional functional value ratings merited special consideration for construction methods and highway designs that would minimize wetland disturbance. Type 3 (shallow marsh) and type 6 (shrub swamp) wetlands are the most common along the proposed highway route. Although less extensive, type 5 (shallow open-water) wetlands were identified as especially important for supporting wild rice beds. Three wetlands selected for monitoring (fig. 1) included a subset of those identified in the supplemental study of wetland features. Wetland 9 consists of types 4, 6, and 7 (deep marshes, shrub swamps, and wooded swamp); wetland 15 is a shallow open-water wetland (type 5) capable of supporting wild rice beds; and wetland 16 consists of types 3 , 4, and 6 (shallow marshes, deep marshes, and shrub swamps).

Seguchie Creek, the stream monitored in this study, flows through several smaller lakes and wetlands before discharging to Mille Lacs Lake (fig. 1). At the upstream end of the reach studied, Seguchie Creek discharges from Holt Lake over a weir. From the weir the stream meanders approximately 1.3 kilometers $(\mathrm{km})$ through a wetland, and then flows through a well-defined channel approximately $0.3 \mathrm{~km}$ before discharging to Mille Lacs Lake. The proposed highway route crosses Seguchie Creek approximately $1.2 \mathrm{~km}$ downstream from the weir, and about $0.4 \mathrm{~km}$ upstream from Mille Lacs Lake. Similar to many streams and lakes in the Mille Lacs Lake area, resort cabins and former cabin sites are located along Seguchie Creek and the north and east shores of Holt Lake, which feeds Seguchie Creek. Several older cabins exist along much of the lower 0.3-km reach of Seguchie Creek near the downstream streamflow-gaging station. Some cabins were removed by the land owner during the timeframe of this study.

Annual precipitation near Mille Lacs Lake averages 70.1 centimeters $(\mathrm{cm})$ at Isle, Minnesota, located $30 \mathrm{~km}$ southeast of the study area (U.S. Department of Commerce, 2007), with $30.5-33 \mathrm{~cm}$ falling during the growing season. Snowfall averages $132-152 \mathrm{~cm}$ per year (Minnesota State Climatology Office, 2006). Monthly-mean temperatures range from -14.4 degrees Celsius $\left({ }^{\circ} \mathrm{C}\right)$ in January to $20.0^{\circ} \mathrm{C}$ in July. Mille Lacs Lake typically is ice covered until April 24 of each year (Minnesota State Climatology Office, 2006).

During the study period (October 2003 to October 2006), annual precipitation averaged $15.2 \mathrm{~cm}$ less than normal. For the months of 2003-06 that are included in the study period, those in 2003, 2004, and 2006 were drier than normal with precipitation departures from normal of $-9.78,-8.13$, and -25.8 $\mathrm{cm}$, respectively (U.S. Department of Commerce, 2004, 2005, 2006, and 2007). Only 2005 was wetter than normal (+21.2 $\mathrm{cm})$. Seasonally, summers tended to be drier than normal with July and August of each year (2004-06) receiving less than normal precipitation (total of $-32.6 \mathrm{~cm}$ for all 3 years). Conversely, the falls of 2004 (September) and 2005 (September and October) were unseasonably wet with $8.17 \mathrm{~cm}$ and 7.39 $\mathrm{cm}$ greater than normal precipitation, respectively. February had greater than normal precipitation each year of the study (total of $2.84 \mathrm{~cm}$ ).

\section{Acknowledgments}

The authors would like to acknowledge and thank the late Curt Eastlund, a Minnesota Department of Transportation employee whose concern and vision made this study possible and who died tragically in a traffic accident on a road very near the highway whose safety he was trying to improve; and James Halgren and John Mackner for their assistance in planning and executing this study. The authors also thank those USGS employees who collected, analyzed, and quality assured most of the field data for this study, including Jeff Copa, Eric Wakeman, and especially Josh Larson.

\section{Methods}

The approach to assess surface-water quality was two tiered: stream monitoring and wetland monitoring. The first tier utilized streamflow monitoring and sampling at Seguchie Creek upstream and downstream from the proposed highway route. By gaging streamflow continuously and sampling the water quality at each site, determination of streamflow and 
constituent concentrations and loads can be made (Bricker, 1999). Differences observed between monitoring sites may be attributed to effects from the road. The low-gradient hydrologic conditions and poorly defined stream channels in the study area complicated this method of comparison between the upstream and downstream sites because most streams are affected by variable backwater from Mille Lacs Lake or wetlands. Backwater introduces uncertainties in streamflow and load computations that can mask the effects introduced by highway activities. Of the few streams that the proposed highway intersects, Seguchie Creek was the most suitable stream for this type of method because of its relatively greater gradient and defined channel at selected reaches. Even so, the stream could not be monitored immediately upstream and downstream from the intersection with the proposed highway route. At this intersection, the stream was not confined to a channel but rather meandered through a wetland (approximately $0.81 \mathrm{~km}^{2}$; fig. 1). Consequently, streamflow-gaging stations were installed at the nearest upstream and downstream locations where flow could be measured accurately.

Methods used to collect stream stage and streamflow are described in Rantz and others (1982), Davidian and Carter (1968), Buchanan and Somers (1969), and Fallon and others (2004). At the downstream gaging station, backwater from Mille Lacs Lake during extremely high water levels could have affected traditional stage-streamflow methods of determining streamflow. To account for backwater, which variably alters the traditional stage-streamflow relation used to compute streamflow, an acoustic Doppler velocity meter was installed to record continuous stream velocities that could be used to compute streamflow using an index velocity-streamflow relation (Morlock and others, 2002). However, velocity measurements during the study indicated that lake levels were not high enough to create backwater conditions at the gaging station, so streamflow was computed using traditional stage-streamflow relations.

In addition to streamflow instrumentation, gaging stations housed continuous water-quality monitors that recorded water temperature and specific conductance at 15-minute intervals. Specific conductance can be used to estimate concentrations of dissolved salts and solids between samplings. The water temperature and specific conductance data were collected according to methods described in Wagner and others (2000) with minor variations. Variations included using a separately calibrated meter placed next to the deployed probe to determine any corrections for meter drift and fouling, rather than removing the deployed probe and calibrating it independently. This variation was necessary because the installation design prohibited removal of the probe for independent calibration.

Stream water-quality samples were collected at or near gaging stations manually and by automatic sampler. Descriptions of sampling methods and the methods used to prepare and process samples are described in the USGS's National Field Manual for the Collection of Water-Quality Data (U.S. Geological Survey, variously dated). For each of the sampling sites on Seguchie Creek, 26 manual water samples were collected during this study at approximately 6-week intervals using methods designed to collect samples representative of the entire stream cross section. Each manual sample was composited from verticals collected along a transect across the river at equal-width increments (EWIs). Because these samples were of relatively high quality with respect to their representation of the entire streamflow, they were analyzed for more constituents than those from automatic samplers (table $1)$.

Automatic samplers collect water from one point in the stream rather than from the entire cross section after being activated from another sensor or remote command. Although these samples are not necessarily representative of the stream cross section, they were useful for collecting water samples from unscheduled rainfall-runoff events when personnel were not available. Typically, these samplers are activated by sensing increases in stream stage. However, the large volumes of water storage available in lakes and wetlands upstream from both gaging stations resulted in very small increases in stage even after heavy rainfall. Instead, samplers were programmed to activate when rainfall sensors indicated rainfall rates greater than 0.13 centimeters per 30 minutes. Automatic samplers were not refrigerated because of their remote locations, so only analyses not needing immediate preservation or treatment (dissolved chloride and suspended sediment) were performed. A total of 64 samples collected by automatic samplers were analyzed. Automated samplers were not used during winter months because sampler lines froze.

The second tier characterized water-quality conditions synoptically at selected wetlands representative of the study area. The types of data collected and frequency of collection are shown in table 1 . Three wetlands were selected for water and bed-sediment sampling based on their classification type and intersection with the proposed highway route. Samples were collected from wetlands during the fall (2003-05) when hydrologic conditions typically are low and stable. For comparing wetland water levels among the years sampled, water levels in wetlands were qualitatively noted based on previous sample holes, and water levels on waders, vegetation, or poles near sampling locations. Water samples were collected by dipping a Teflon bottle into the wetland at several (three to five) locations immediately outside the construction area of the proposed highway route and compositing these samples into one container. Water samples were processed similarly to those described for Seguchie Creek. Occasionally, water levels in wetlands were below the surface vegetative layer. In these cases, the vegetative material was separated or removed so that the sample bottle could be dipped and filled. Sample locations were recorded by global positioning system and revisited each year so that annual variation could be assessed. Sample locations frequently could be verified in subsequent years by locating holes in the vegetation made during previous samplings. Water samples were analyzed for dissolved and total nutrients.

Bed-sediment samples were collected for two analyses: particle size and chemical. Each analysis type used different 


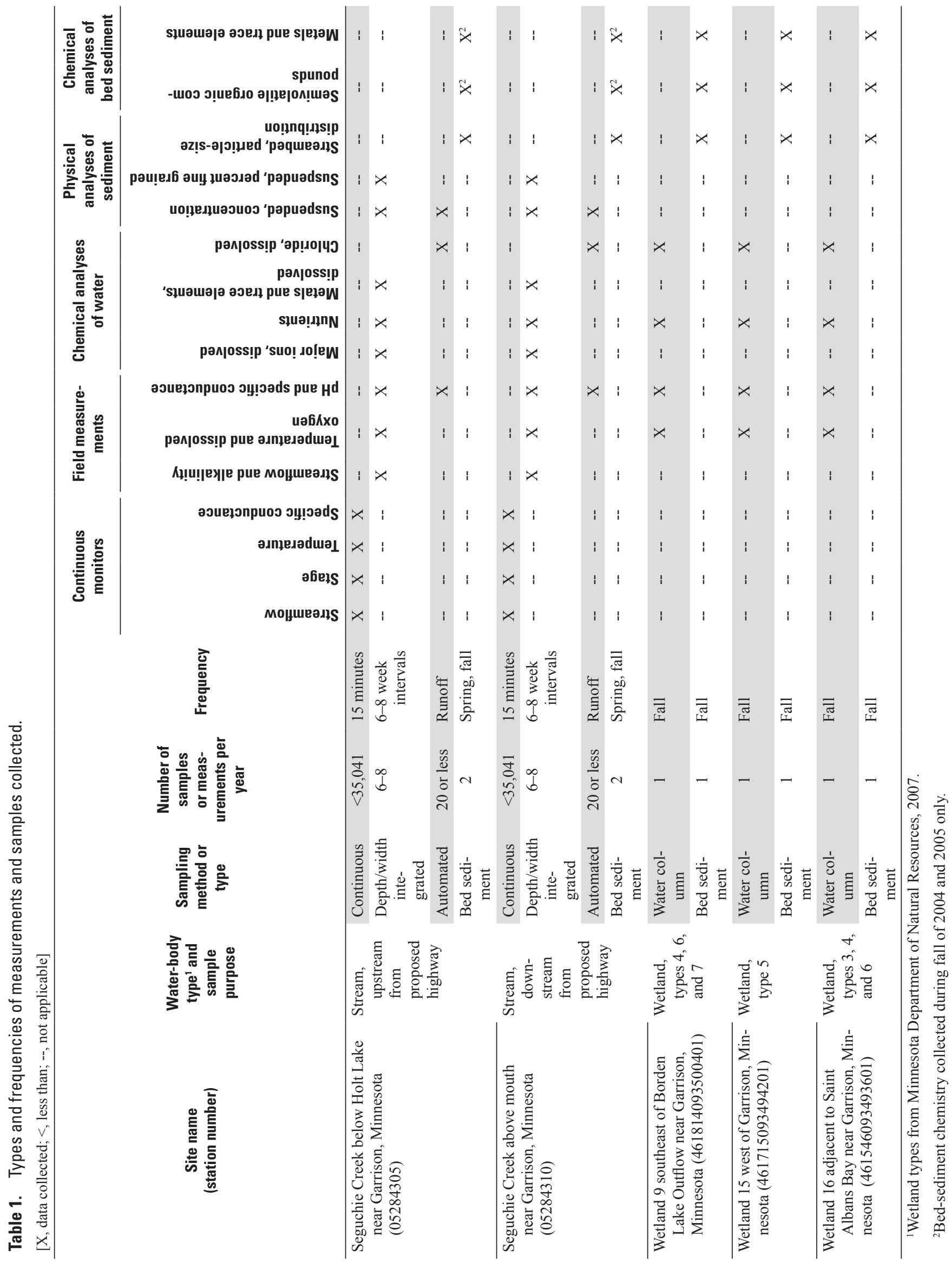


collection methods. In Seguchie Creek, bed-sediment samples for particle-size analyses were collected according to methods outlined in Guy (1977). These samples were collected at equal-width increments across the stream to characterize the size distribution of bed sediment representative of the entire stream cross section. The upper $5 \mathrm{~cm}$ of sediment were collected from each interval. Samples were collected during spring and fall when streamflow was expected to be seasonally high or low, respectively, to determine possible differences in the size distribution resulting from stream energy levels. For chemical analyses, bed-sediment samples were collected using methods described in Shelton and Capel (1994). Instead of collecting samples from the entire cross section, these samples were collected from depositional areas in the stream having slow velocities. Slower velocities preferentially deposit finergrained sediments that tend to have greater concentrations of metal and organic contaminants. The upper $1-2 \mathrm{~cm}$ of material was collected to characterize the chemical composition of the most recent fine-grained sediment deposits. Samples for analyses of organic material were passed through a 2-millimeter $(\mathrm{mm})$ sieve to remove larger particles. Samples for metals and trace elements were passed through a 63-micron sieve to remove larger material typically not associated with trace element adsorption.

In wetlands, bed-sediment samples were collected to assess baseline characteristics of particle size and chemistry. In each wetland, subsamples were collected from several locations parallel to and immediately outside of the planned construction zone. Each set of subsamples was composited into one sample for analysis. Bed-sediment sampling in wetlands was complicated by two of the three wetlands having little or no mineral sediment; rather, particles were composed of decaying vegetation. Consequently, wetland-sediment data are not directly comparable to streambed-sediment data. For size analyses, this decaying vegetative "bed material" was collected using glass scoops from the locations described previously for wetland water sampling. Similarly, samples for chemical analyses also were collected using modified methods; bed material was collected at the water level if vegetation extended above and covered the water. Preparation of samples for chemical analyses was problematic because vegetative material would not pass through the sieves. After consulting laboratory staff, samples were not sieved because methods used to analyze samples digested all of the organic material regardless of particle size.

All water and bed-sediment samples collected for chemical analysis were shipped on ice to the USGS's National Water Quality Laboratory in Denver, Colorado. The water samples were analyzed using methods described by Fishman (1993), Fishman and Friedman (1989), Gabarino and others (2006), Patton and Kryskalla (2002), and Patton and Truitt (2000); bed-sediment samples were analyzed using methods described by Furlong and others (1996) and Taggart (2002). Samples for bed- and stream-sediment size analyses were performed by a USGS Sediment Laboratory in Iowa City, Iowa, using methods described by Guy (1977). Many minor constituents in water and bed sediment are reported as estimated concentrations (E-coded values in summary tables) that are less than the long-term method detection levels (LTMDL); the chance of falsely reporting a concentration at or greater than the LTMDL for a sample that did not contain the constituent is predicted to be less than or equal to 1 percent (Childress and others, 1999). These results are appropriate for characterizing particular constituents as "detected" or present in the sample but not for interpreting a collection of data. Other samples reporting censored values also may have had the same constituents present in their respective samples, but for any one of many reasons, the concentration could not be quantified.

Thirteen quality-assurance samples were collected for water samples to document and quantify possible contamination, bias, and variability. Types of quality-assurance samples included equipment blanks and replicates.

Seven equipment blanks for water samples were collected to assess bias introduced by equipment cleaning and handling and by sampling, processing, and analysis. Twentyfour constituents were analyzed, including nutrients, dissolved ions and metals, and suspended sediment. Eight constituents were detected in blanks: dissolved ammonia, total nitrogen, dissolved calcium, silica, barium, copper, zinc, and suspended sediment. Of these, dissolved ammonia, calcium, and copper were not detected in the equipment blanks at concentrations greater than the LTMDLs used in this report, so these do not affect interpretive results. Detections of total nitrogen, dissolved calcium, silica, and barium were 10 to 100 times less than concentrations in environmental samples, so similarly do not affect results. Zinc was detected in the laboratory check of blank water prior to field use, so zinc concentrations in the equipment blank could be partly attributed to the blank water. Suspended sediment was detected once at a concentration equal to the LTMDL. Results of the equipment blanks indicate that samples were not substantially biased by carry-over contamination.

Two types of eight replicates were collected for water samples. Five split replicates were collected to measure variability introduced in the processing and analysis of samples. Split replicate samples had little variability between split samples, indicating minimal variability was introduced by laboratory analysis. Three concurrent replicates were collected from the automatic samplers and manual EWI samples for analyses of suspended sediment to compare results between the two sampling methods. These samples had a wider range of variability. EWI replicates had suspended-sediment concentrations of less than $(<) 1,2$, and 4 milligrams per liter $(\mathrm{mg} / \mathrm{L})$, whereas, the respective replicates from the automatic sampler had concentrations of 7, 8, and $5 \mathrm{mg} / \mathrm{L}$. EWI sampling methods are designed to collect samples representative of the stream cross section and velocity. Automated samplers have been shown to introduce variability when used for suspended particles (Ging, 1999) because these samplers withdraw water from only one point in the stream, do not sample isokinetically, and disturb the water column by purging sampler lines when preparing to sample. Consequently, the sources of 
variability of suspended-sediment concentrations and other constituents associated with suspended sediment should be considered when evaluating data. In spite of the limitations, automated samplers were used because of the void filled in sampling runoff events when personnel were not onsite.

The National Water Quality Laboratory reported instrument matrix interference issues for selected constituents in bed sediment. Affected results were not reported and were coded as "na" in the data summaries. Quality assurance for bedsediment analyses consisted of repeated sampling of the same locations during each of the 3 years sampled. These results helped to characterize temporal variability and sensitivity of analytical results because of sampling location.

To compare constituent concentrations between sites on Seguchie Creek, a Wilcoxon rank-sum test (Wilcoxon, 1945), also known as a Mann-Whitney test (Mann and Whitney, 1947), was used. This nonparametric test determines whether two sets of observations are from the same distribution for data with small sample sizes and without assuming the data are normally distributed.

Loads were computed for dissolved chloride, dissolved ammonia plus organic nitrogen, total phosphorus, and suspended sediment. Loads were not computed for other nutrients because of insufficient data (dissolved phosphorus and total nitrogen) or for insufficient detections of constituents (ammonia nitrogen, dissolved nitrite, nitrite plus nitrate nitrogen, and orthophosphate). Loads were computed using LOADEST2 using data from continuous streamflow and specific conductance monitors and from discrete water-quality analyses at the upstream and downstream Seguchie Creek sites. LOADEST2 is a regression-based, multiparameter statistical model (Runkel and others, 2004). Transport curves for each waterquality constituent are developed based on coefficients from multiple regression models. Calibration data consist of natural log-transformed values of instantaneous streamflow, specific conductance in microsiemens per centimeter at $25^{\circ} \mathrm{C}(\mu \mathrm{S} / \mathrm{cm})$, instantaneous concentrations of water-quality constituents (dissolved chloride, selected nutrients [including dissolved ammonia plus organic nitrogen, and total phosphorus], and suspended sediment) in milligrams per liter, and decimal time. Data were censored at the LTMDLs, which generally were less than the method reporting levels (MRL).

Regression coefficients for slope, intercept, season, and time from the calibration data were used to construct models that estimated daily water-quality constituent loads from daily streamflow and specific conductance. Combinations of the natural log of streamflow, the natural log of specific conductance, representations of seasonality that include time, sine (time), and cosine (time) were tested to determine the best regression equations for each site and constituent. Various models were evaluated for best fit, including the Adjusted Maximum Likelihood Estimate (AMLE) method and the Least Absolute Deviation (LAD) method. The AMLE method was used for constituents with concentrations censored below the LTMDL. The LAD method was used for constituents with all concentrations reported above the LTMDL but with data that were not normally distributed. For a given constituent, the same equation variables and models were used for load computations at upstream and downstream sites to minimize variability caused by the model itself. Results are reported in kilograms per day.

\section{Seguchie Creek}

Two streamflow-gaging stations with water-quality monitors were installed on Seguchie Creek: Seguchie Creek at Holt Lake outlet, near Garrison, Minnesota (station 05284305), hereinafter referred to as the upstream gage or site; and Seguchie Creek above mouth, near Garrison, Minnesota (station 05284310), hereinafter referred to as the downstream gage or site. The upstream gage has a drainage area of $43.2 \mathrm{~km}^{2}$, and the downstream gage has a drainage area of $44.8 \mathrm{~km}^{2}$. The drainage area of the downstream gage is 3.5 percent greater than the drainage area of the upstream gage.

\section{Streamflow}

Streamflow was measured from May 26, 2004, when gaging stations became operational, to September 30, 2006 (fig. 2). Streamflow at the downstream gage generally was slightly greater than at the upstream gage, indicating that Seguchie Creek is a gaining stream. For the period of record, the mean streamflow at the downstream gage of 0.22 cubic meter per second $\left(\mathrm{m}^{3} / \mathrm{s}\right)$ was 5.6 percent greater than the mean streamflow at the upstream gage of $0.21 \mathrm{~m}^{3} / \mathrm{s}$. This difference is within the measurement error for streamflow. However, the consistent pattern of greater streamflow at the downstream gage indicates that the greater drainage area resulted in slightly greater streamflow compared to the upstream gage.

Daily-mean streamflow ranged from 0 to $0.83 \mathrm{~m}^{3} / \mathrm{s}$ at the upstream gage and from 0 to $0.87 \mathrm{~m}^{3} / \mathrm{s}$ at the downstream gage. Increases in flow were gradual even during intense precipitation periods because of the large amount of storage immediately upstream from both gages: the lake outflow at the upstream gage and the wetland upstream from the downstream gage. Days with no flow were observed more frequently at the upstream gage (59 days) than at the downstream gage (47 days) because streamflow would cease from the lake at the upstream gage while the downstream gage continued to record flow draining from the wetland located between the two gages. Conversely, during winter, ice affected and decreased streamflow more at the downstream gage than at the upstream gage (fig. 2, January 2005 and February 2006); fast stream velocities over the weir outflow kept the upstream gage open and flowing, whereas, slower stream velocities through the wetland and downstream site resulted in ice formation and storage.

Streamflow measured for this study was compared to the water budgets simulated for the MNDOT in 2001 to assess the potential effects of highway construction on Mille Lacs Lake (Curt Eastlund, Minnesota Department of Transportation, 


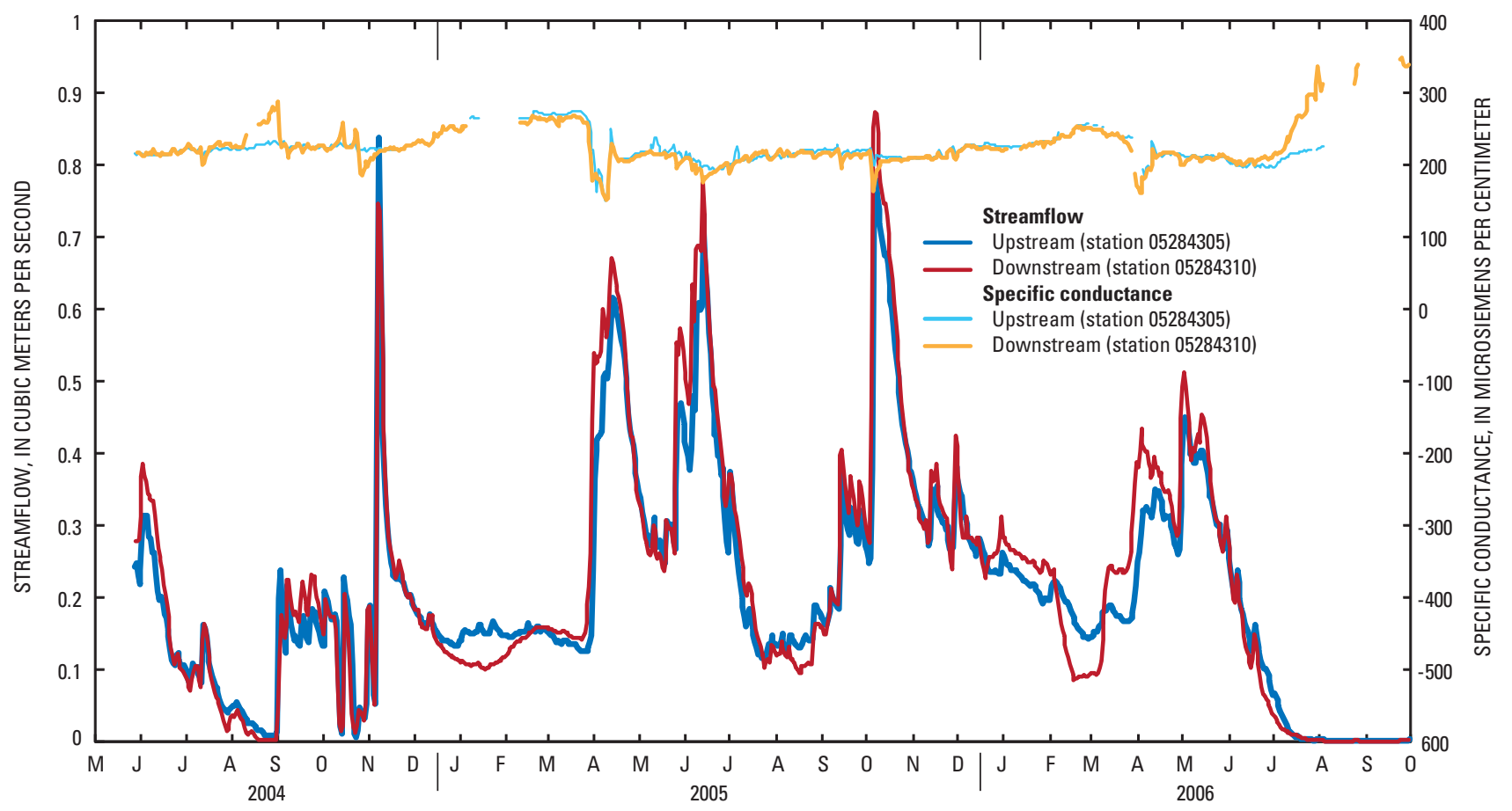

Figure 2. Daily-mean streamflow and specific conductance at upstream and downstream gaging stations on Seguchie Creek near Garrison, Minnesota.

written commun., 2003). The model was calibrated by using streamflows estimated from Holt Lake into Seguchie Creek on the basis of data from calendar year 2000 and by using $58 \mathrm{~cm}$ of annual precipitation. Scenarios were simulated with other precipitation amounts, including normal $(70 \mathrm{~cm})$ and wet $(87$ $\mathrm{cm})$. Simulated streamflows from Holt Lake were 2.46 cubic hectometers per year $\left(\mathrm{hm}^{3} / \mathrm{yr}\right), 5.80 \mathrm{hm}^{3} / \mathrm{yr}$, and $10.93 \mathrm{hm}^{3} / \mathrm{yr}$ for the three increasing precipitation amounts of $58 \mathrm{~cm}, 70 \mathrm{~cm}$, and $87 \mathrm{~cm}$, respectively. In this study, precipitation amounts corresponding to the periods with streamflow data for 2004 (May 26 to December 31), 2005 (all), and 2006 (January 1 to September 30) were $41.1 \mathrm{~cm}, 91.4 \mathrm{~cm}$, and $40.1 \mathrm{~cm}$, respectively, while streamflow averaged $4.46 \mathrm{hm}^{3} / \mathrm{yr}, 9.00 \mathrm{hm}^{3} / \mathrm{yr}$, and $4.93 \mathrm{hm}^{3} / \mathrm{yr}$, respectively. Thus, streamflow measured during the partial years (2004 and 2006) was as much as two times greater than those simulated for the MNDOT in 2001 even though precipitation during the partial years was about $15 \mathrm{~cm}$ less. Conversely, the 2005 streamflow measured during this study $\left(9 \mathrm{hm}^{3} / \mathrm{yr}\right)$ was less than the simulated streamflow of $10.93 \mathrm{hm}^{3} / \mathrm{yr}$ even though 2006 precipitation was slightly greater $(91.4 \mathrm{~cm})$ than the simulated precipitation $(87 \mathrm{~cm})$.

\section{Water Quality}

Seguchie Creek was sampled at both monitoring sites (stations 05284305 and 05284310 ) for chemical constituents that commonly are associated with highway construction and operation. These include dissolved major ions, dissolved and total nutrients, dissolved metals and trace elements, and concentration and size analyses of suspended sediment.
Water-quality data collected for this study for the Seguchie Creek sites are available at http://nwis.waterdata.usgs.gov/mn/ nwis/qwdata.

\section{Concentrations and Physical Properties}

Statistical summaries of constituent concentrations in water are presented in table 2 (at the back of this report). When applicable, State of Minnesota water-quality standards (Minnesota Office of the Revisor of Statutes, 2007) are included. Concentrations generally were low. No constituent concentrations exceeded applicable standards. However, dissolved-oxygen concentrations at the downstream site were less than the daily minimum of $4.0 \mathrm{mg} / \mathrm{L}$ for 6 of 26 measurements. These minima occurred during July to October.

The ranges of most concentrations were nearly identical between sites, including those for dissolved calcium, magnesium, alkalinity, bicarbonate, fluoride, silica, dissolved solids, nitrite plus nitrate, nitrite, orthophosphate, cadmium, chromium, molybdenum, silver, and suspended sediment. Similarly, median concentrations of most constituents varied less than 5 percent between upstream and downstream sites. Those with differences greater than 5 percent between median concentrations included dissolved copper, iron, manganese, nickel, and zinc. Median concentrations of dissolved iron, manganese, nickel, and zinc were greater at the downstream site. Dissolved iron was the only constituent with significantly different concentrations ( $<<0.05$, Wilcoxon rank sum test) between upstream and downstream sites.

As the study progressed, concentrations of selected metals and trace elements from the downstream site occasionally 
were greater than those from the upstream site for pairs of samples collected the same day. Samples from the downstream site were collected upstream from the current highway (fig. 1), and all but one were collected upstream from the small service road bridge upstream from the current highway, so the increase in metals and trace elements between the sites was assumed to not be associated with highway or roadway activities. Because most of the reach between monitoring sites consists of wetlands, which were not thought to be a source of metals and trace elements, it was hypothesized that these greater concentrations at the downstream site may have resulted from previous activities associated with cabins located along the stream reach just upstream from the downstream gage. To determine if activities associated with the cabins may have been a source of metals and trace elements, beginning May 4, 2005, the sampling location for the manual samples for the downstream site was moved to be upstream from the cabin-lined reach (approximately 150 meters upstream from the downstream gage) to determine if there was a difference in concentrations upstream and downstream from the cabins (table 3, at the back of this report). A Wilcoxon rank sum test was used to compare concentrations for samples collected before May 4, 2005, with those collected after May 4, 2005, with censored values ranked lowest. Concentrations of dissolved cobalt and magnesium were significantly different ( $<<0.05$, Wilcoxon rank sum test) and greater downstream from the cabins, whereas, concentrations of dissolved nickel and zinc were significantly different ( $\mathrm{p}<0.05$, Wilcoxon rank sum test) and greater upstream from the cabins. Consequently, no clear spatial pattern was observed.

Some constituents had one or two anomalously large, or outlier, concentrations at one site or the other. For example, concentrations of dissolved lead in two samples from the upstream site were three to five times greater than any other samples. The greatest concentrations of dissolved manganese and iron were in samples from the downstream site. Dissolved manganese and iron concentrations generally increased with decreasing dissolved-oxygen concentrations.

Fifteen of the 21 constituents in table 2 had greater variability downstream than upstream. These include discrete measurements of dissolved oxygen, $\mathrm{pH}$, specific conductance, and dissolved constituents of potassium, sodium, chloride, ammonia plus organic nitrogen, ammonia, phosphorus, aluminum, antimony, barium, beryllium, cobalt, and nickel.

Continuous specific conductance values were more variable at the downstream site than the upstream site (fig. 2). During the study period, continuous specific conductance values ranged from 130 to $290 \mu \mathrm{S} / \mathrm{cm}$ at the upstream site, and from 144 to $357 \mu \mathrm{S} / \mathrm{cm}$ at the downstream site (these extremes are instantaneous observations and not shown as daily-mean values in fig. 2). During dry periods with streamflow recessions, specific conductance at the downstream site would increase at a greater rate and generally peak at a greater value than at the upstream site. Similarly during periods of precipitation and runoff, specific conductance at the downstream site would decrease at a greater rate and to a lesser value than at the upstream site.

\section{Loads}

Loads were computed for dissolved chloride, dissolved ammonia plus organic nitrogen, total phosphorus, and suspended sediment. Two models were selected to compute loads. The AMLE model was used for total phosphorus and suspended sediment because these constituents had concentrations censored below the LTMDL (table 4). The LAD model was used for dissolved chloride and dissolved ammonia plus organic nitrogen because these data were not normally distributed and because all concentrations were greater than the LTMDL. Loads are presented in table 5. The lower and upper 95th-percent confidence intervals were included as part of the model output for those constituents computed using the AMLE method and are included in table 5 for total loads.

Total loads for the period of the study were greater at the downstream site than at the upstream site. Loads were 1.7 percent greater for dissolved chloride, 13 percent greater for dissolved ammonia plus organic nitrogen, 62 percent greater for total phosphorus, and 11 percent greater for suspended sediment between the upstream and downstream sites.

Constituent loads had a seasonal distribution. For seasonal analysis, loading rates were summed by climatological season as spring (March to May), summer (June to August), fall (September to November), and winter (December to February). All four constituents had peaks in spring and fall. Suspended sediment especially had the greatest loading rates during the fall, and the large gains in suspended-sediment loads at the downstream site compared to the upstream site occurred during these fall peaks.

Total phosphorus loading rates for the upstream site for this study can be compared with those produced for the nutrient and water budgets simulated for the MNDOT in 2001 (Curt Eastlund, Minnesota Department of Transportation, written commun., 2003). The model was used to simulate loading rates of phosphorus discharged from Holt Lake into Seguchie Creek for various scenarios using 2000 data for model calibration. For the three precipitation scenarios (dry, normal, and wet) noted in the Introduction section, the estimated total phosphorus loading rates from the simulations were 42.6, 118.1 , and 256.6 kilograms per year $(\mathrm{kg} / \mathrm{yr})$, respectively. Loads for the simulated wet scenario are roughly 1.5 times greater than those calculated in this report. For example, for the 2005 calendar year, with measured precipitation of 91.4 $\mathrm{cm}$ and mean annual streamflow of $0.28 \mathrm{~m}^{3} / \mathrm{s}$ from Holt Lake, a total phosphorus loading rate of $166 \mathrm{~kg} / \mathrm{yr}$ was estimated (table 5; lower and upper 95-percent confidence intervals of 123 and $220 \mathrm{~kg} / \mathrm{yr}$, respectively), compared to the 2001 simulated loading rate of $256.6 \mathrm{~kg} / \mathrm{yr}$ for the model's wet scenario with roughly equal precipitation $(87 \mathrm{~cm})$ and slightly greater streamflow $\left(0.34 \mathrm{~m}^{3} / \mathrm{s}\right.$ or $\left.10.93 \mathrm{hm}^{3} / \mathrm{yr}\right)$. Confidence intervals were not available for the simulated results from the nutrient and water budget model for the MNDOT. It is possible that the 

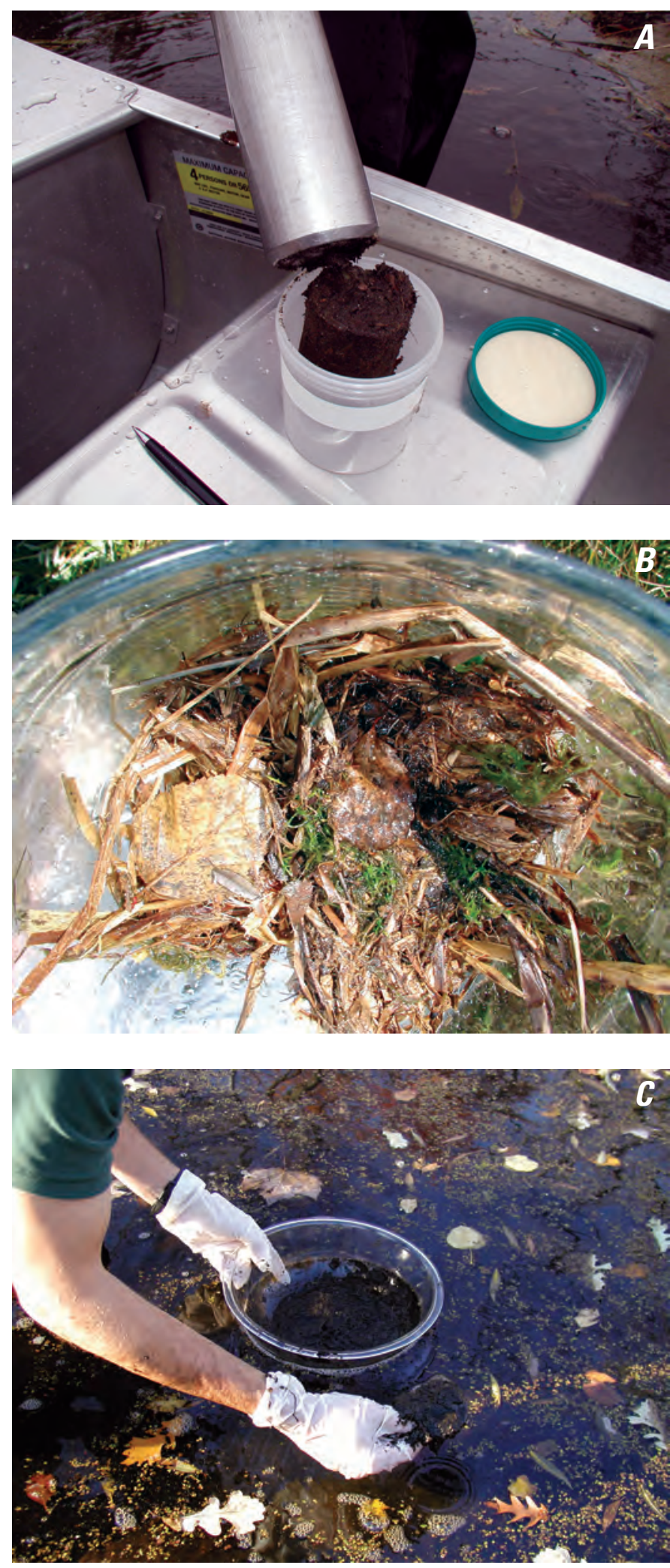

Figure 3. Bed-sediment samples collected from (A) Seguchie Creek for particle size analysis, $(B)$ wetland 16 for particle size and chemical analyses, and $(C)$ wetland 15 for particle size and chemical analyses. confidence intervals for the loads for this report and those for the simulated loads for the MNDOT (Curt Eastlund, Minnesota Department of Transportation, written commun., 2003) overlap.

\section{Bed-Sediment Quality}

Bed-sediment samples were collected at the two Seguchie Creek sites to assess the size distribution of sediment particles and the chemical composition of the sediment. The typical compositions of bed-sediment samples collected in this study are shown in figure 3. Bed-sediment data for the sampled sites are available at http://nwis.waterdata.usgs.gov/mn/nwis/ qwdata.

Bed-sediment samples for chemical analysis were collected to assess contaminants associated with highway construction and operation. The electrochemical charges of small-grained sediments (silt and clay sized) attract hydrophobic contaminants carried in water. These contaminants adsorb to sediments.

No bed-sediment-quality standards or guidelines exist in the United States, so Canadian guidelines were used for reference in this report. The Canadian Council of Ministers of the Environment (CCME) created advisory guidelines for concentrations of organic compounds and metals after examining the effects of these contaminants in bed sediment on aquatic life (Canadian Council of Ministers of the Environment, 1995). Concentrations found in this study were compared with Interim Sediment Quality Guidelines (ISQGs) and Probable Effect Levels (PELs), which were designed according to toxicological data regarding the biological effects of chemicals associated with sediment on aquatic life (Canadian Council of Ministers of the Environment, 1995). Bed-sediment concentrations that are between the ISQG and PEL values are associated with adverse biological effects. When bed-sediment concentrations exceed the PEL, potentially damaging effects are expected (Canadian Council of Ministers of the Environment, 1995). Applicable guidelines are included in summary data tables.

\section{Size}

Samples for bed-sediment size analyses were collected during the fall and spring, October 2003 to October 2006, to characterize ranges in bed-sediment particle size across the stream cross-section at each site during seasonally high- and low-flow periods. Greater streamflow typical of spring can move and deposit larger bed-sediment particle sizes than lower streamflow typical of fall when more deposition of smaller particle sizes would result. The bed sediment at each stream site was sampled seven times. Like the water-sampling location at the downstream site, the bed-sediment sampling location was moved from a pool immediately upstream from the gage to a narrower section farther upstream to limit potential influence of land use near the stream beginning May 4, 2005. 
Particle-size distributions were determined as weight percent of the sample within the particular size classification.

Bed-sediment particle sizes analyzed ranged from clay (less than $0.004 \mathrm{~mm}$ ) to very coarse pebbles (64 mm, fig. 4). Larger cobble-sized particles were present in the stream but were too large for the sampler to collect.

The particle-size distribution was different between the upstream and downstream sites. The downstream site generally had the greatest proportion of sand- and larger-sized particles (particle sizes greater than $0.062 \mathrm{~mm}$ ). For example, the median particle size at the downstream site was $0.5 \mathrm{~mm}$ compared to $0.25 \mathrm{~mm}$ at the upstream site. Similarly, 35 percent of the particles were larger than $1.0 \mathrm{~mm}$ at the downstream site compared to only 20 percent at the upstream site. The downstream site had greater variability in larger particle sizes; the percentage of particles smaller than $4 \mathrm{~mm}$ ranged from 45 to 96 percent at the downstream site compared to 68 to 99 percent at the upstream site. The median particle size per sample ranged from 0.5 to $8.0 \mathrm{~mm}$ at the downstream site and from 0.25 to $1.0 \mathrm{~mm}$ at the upstream site. The upstream site had a greater proportion of samples composed of silt- and clay-sized particles (particles less than $0.063 \mathrm{~mm}$; 4 percent) than the downstream site ( 2 percent).

\section{Metals and Trace Elements}

Two bed-sediment samples from each of the Seguchie Creek sites (one in the fall of 2004 and one in the fall of 2005) were analyzed for concentrations of 42 metals and trace elements (table 6). Unless otherwise noted, concentrations in table 6 are reported in micrograms per gram $(\mu \mathrm{g} / \mathrm{g})$, which is equivalent to parts per million. For comparative reference, CCME guidelines (Canadian Council of Ministers of the Environment, 2002) as well as concentrations of bed-sediment samples collected from a U.S. Geological Survey study of the Upper Mississippi River Basin during 1995-96 (Kroening and others, 2000) are included.

All 42 metal and trace elements analyzed during this study were detected in at least one bed-sediment sample. For constituents detected in both years sampled (2004 and 2005), variability in concentrations ranged from 0 to 168 percent with a median of 15 percent. Large amounts of variability are not uncommon in chemical analyses of bed sediment. Variations in analytical results can result from analytical complications such as matrix interference (Briggs and Meier, 1999) and from environmental variability in time or space.

Six of the metals and trace elements detected have corresponding ISQGs and PELs (Canadian Council of Ministers of the Environment, 2002): arsenic, cadmium, chromium, copper, lead, and zinc. Concentrations of 5 of the 6 elements (arsenic, cadmium, chromium, lead, and zinc) exceeded corresponding ISQGs at one or both Seguchie Creek sampling sites, and concentrations of lead at the upstream site exceeded the PEL. Arsenic concentrations at both the upstream and downstream sites exceeded the ISQG of $5.9 \mu \mathrm{g} / \mathrm{g}$. Cadmium concentrations at the upstream site exceeded the $0.60 \mu \mathrm{g} / \mathrm{g}$ ISQG. Chromium

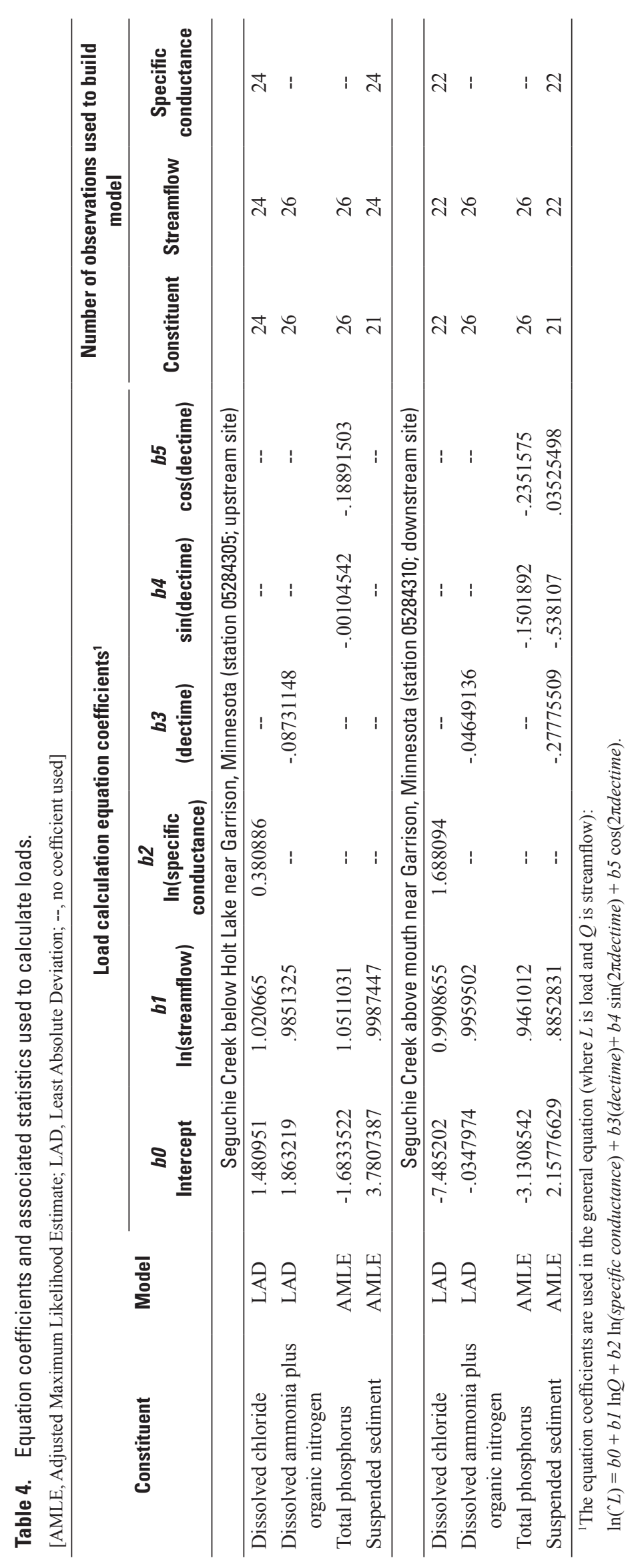




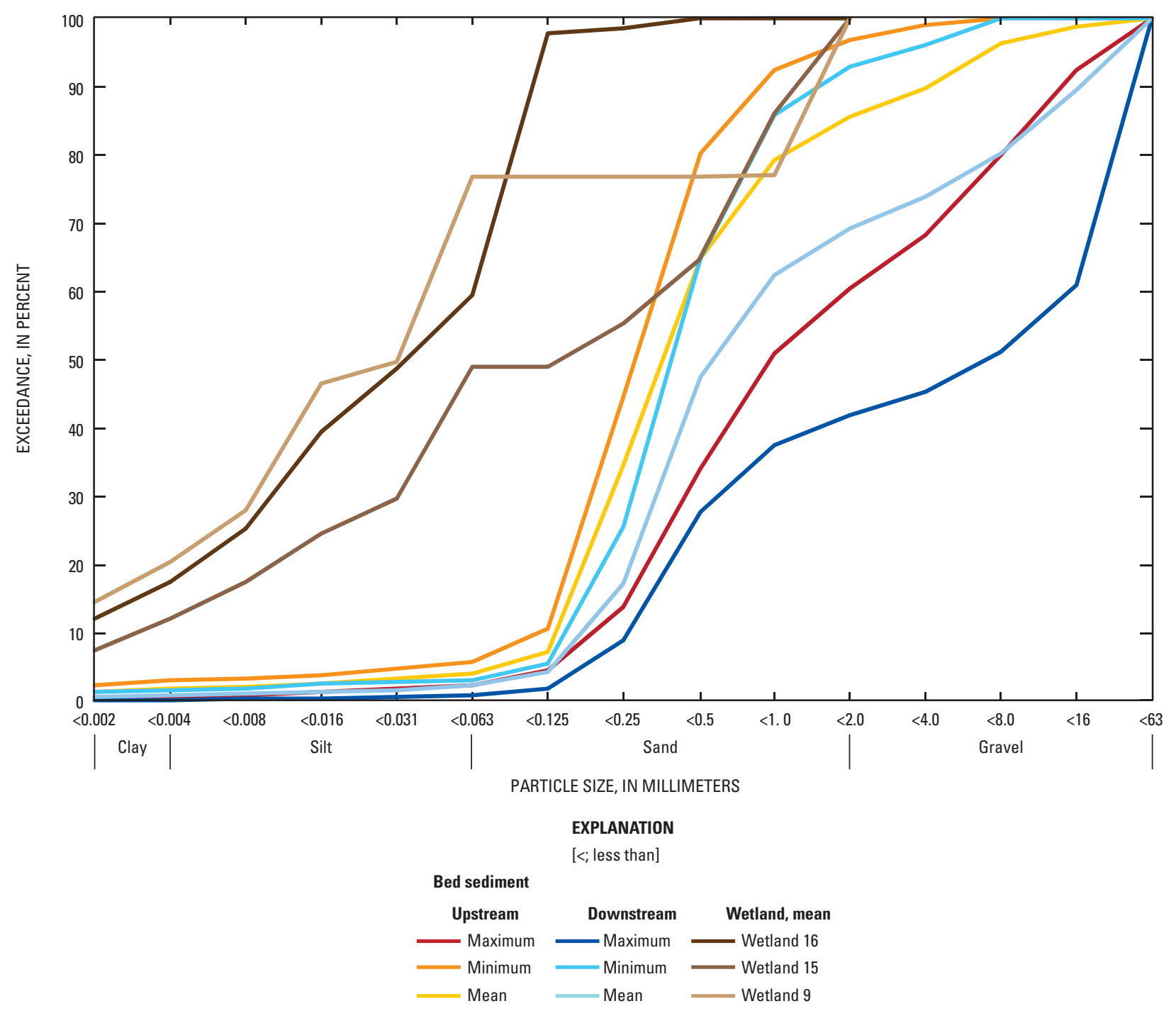

Figure 4. Particle-size distribution of bed sediment in upstream and downstream Seguchie Creek sites and wetlands, near Garrison, Minnesota, October 2003 to October 2006.

concentrations at both the upstream and downstream sites exceeded the ISQG of $37.3 \mu \mathrm{g} / \mathrm{g}$. Lead concentrations at the upstream site exceeded the potentially damaging PEL of 91.3 $\mu \mathrm{g} / \mathrm{g}$. As a reference value, the median lead concentration of $23.0 \mu \mathrm{g} / \mathrm{g}$ from sites sampled throughout the Upper Mississippi River Basin was substantially less than the upstream and PEL concentrations. Zinc concentrations at the upstream site exceeded the ISQG of $123 \mu \mathrm{g} / \mathrm{g}$. Only copper concentrations at both sites were less than the ISQG of $35.7 \mu \mathrm{g} / \mathrm{g}$. More samples from the upstream site (seven) had concentrations that exceeded CCME ISQGs than the downstream site (two).

No ISQG exists for tin. One sample had a tin concentration of $24 \mu \mathrm{g} / \mathrm{g}$ at the upstream site-more than four times greater than the median value of $<5.0 \mu \mathrm{g} / \mathrm{g}$ in samples from across the Upper Mississippi River Basin in Minnesota and Wisconsin (Kroening and others, 2000).

\section{Organic Compounds}

Two bed-sediment samples from each of the Seguchie Creek sites (one in the fall of 2004 and one in the fall of 2005) were analyzed for a suite of 78 semivolatile organic compounds. Twenty-five of these compounds were detected in Seguchie Creek (table 7). Concentrations in table 7 are reported in micrograms per kilogram $(\mu \mathrm{g} / \mathrm{kg})$, which is equivalent to parts per billion - concentrations approximately 1,000 times less than those for metals and trace elements in bed sediment. Detections consisted of PAHs, phthalates, and phenols. Variability in concentrations from year to year was greater for the organic compounds than for the metals and trace elements. For compounds detected in both years sampled (2004 and 2005), variability ranged from 51 to 3,400 percent, with a median of 224 percent.

All 20 PAHs analyzed were detected in Seguchie Creek. Concentrations of 11 compounds exceeded their respective 
CCME ISQGs: ancenaphthene, acenaphthylene, anthracene, benzo $[a]$ anthracene, benzo $[a]$ pyrene, chrysene, fluoranthene, fluorene, naphthalene, phenanthrene, and pyrene. In addition, acenapthene, acenaphthylene, benzo $[a]$ pyrene, and fluorene exceeded their respective PELs. Concentrations of all 11 PAHs that exceeded ISQGs were greater in the sample collected downstream from the cabins (2004) than in the sample collected upstream from them (2005), indicating possible sources from previous activities in this reach.

Of the 11 PAHs that exceeded their respective ISQGs, acenapthene concentrations at both the upstream and downstream sites exceeded the PEL of $88.9 \mu \mathrm{g} / \mathrm{kg}$. Acenaphthylene concentrations exceeded the ISQG of $5.87 \mu \mathrm{g} / \mathrm{kg}$ at both sites and the PEL of $128 \mu \mathrm{g} / \mathrm{kg}$ at the downstream site. Anthracene concentrations exceeded the ISQG of $46.9 \mu \mathrm{g} / \mathrm{kg}$ at the downstream site. Benzo[a]anthracene concentrations exceeded the ISQG of $31.7 \mu \mathrm{g} / \mathrm{kg}$ at both sites and the PEL of $385 \mu \mathrm{g} / \mathrm{kg}$ at the downstream site. Benzo[a]pyrene concentrations exceeded the ISQG of $31.9 \mu \mathrm{g} / \mathrm{kg}$ at the downstream site. Chrysene exceeded the ISQG of $57.1 \mu \mathrm{g} / \mathrm{kg}$ at the downstream site. Fluoranthene concentrations at both sites exceeded the ISQG of $111 \mu \mathrm{g} / \mathrm{kg}$. Fluorene concentrations exceeded the ISQG of $21.2 \mu \mathrm{g} / \mathrm{kg}$ and the PEL of $144 \mu \mathrm{g} / \mathrm{kg}$ at the downstream site, whereas, concentrations at the upstream site were less than the reporting level. Naphthalene concentrations at both sites exceeded the ISQG of $34.6 \mu \mathrm{g} / \mathrm{kg}$. Phenanthrene concentrations at both sites exceeded the ISQG of $41.9 \mu \mathrm{g} / \mathrm{kg}$. Finally, pyrene concentrations at both sites exceeded the ISQG of 53.0 $\mu \mathrm{g} / \mathrm{kg}$. Most exceedances of CCME guidelines for semivolatile organic compounds ( 20 of 28 exceedances) occurred at the downstream site, in contrast to more exceedances for metals and trace elements at the upstream site ( 7 of 9 exceedances).

Other semivolatile organic compounds detected in Seguchie Creek were three phthalates (2,6-dimethylnaphthalene, 2-ethylnaphthalene, and bis(2-ethylhexyl) phthalate) and two phenols ( $p$-cresol and phenol). Frequency of detections and concentrations generally were similar between the sites with the exception of bis(2-ethylhexyl) phthalate, which had an estimated concentration of $1,100 \mu \mathrm{g} / \mathrm{kg}$ at the downstream site - nine times greater than the upstream concentration. The compound $p$-cresol was detected once at the upstream site and twice at the downstream site with estimated concentrations ranging from 74.0 to $260 \mu \mathrm{g} / \mathrm{kg}$. Phenol was detected once at each site with estimated concentrations ranging from 56.0 to $190 \mu \mathrm{g} / \mathrm{kg}$. No environmental guidelines exist for these other semivolatile organic compounds.

\section{Wetlands}

Three wetlands selected for monitoring included a subset of those identified in the supplemental study of wetland features for MNDOT (Curt Eastlund, Minnesota Department of Transportation, written commun., 2003). Wetland 9 consists of types 4, 6, and 7 (deep marshes, shrub swamps, and wooded swamps); wetland 15 is a shallow open-water wetland (type 5); and wetland 16 consists of types 3, 4, and 6 (shallow marshes, deep marshes, and shrub swamps).

Water levels in wetlands were qualitatively observed and noted based on previous sample holes, water levels on waders, and vegetation near sampling locations. In the marshy wetlands 9 and 16, levels were lowest in 2003 and were higher by a few centimeters each successive year. No change was noted in the open-water wetland 15 .

\section{Water Quality}

Three water samples from each of the wetlands were collected for analysis of the nutrients dissolved ammonia plus organic nitrogen, ammonia, nitrite plus nitrate, nitrite, orthophosphate, phosphorus, and total phosphorus (table 8). At each location, dissolved oxygen, $\mathrm{pH}$, specific conductance, and water temperature were measured (table 8).

The most frequently detected nutrients with the greatest concentrations were dissolved ammonia plus organic nitrogen, total phosphorus, dissolved phosphorus, and ammonia. Dissolved ammonia plus organic nitrogen concentrations ranged from 1.2 to $38.1 \mathrm{mg} / \mathrm{L}$. Dissolved phosphorus concentrations ranged from less than 0.04 to $0.13 \mathrm{mg} / \mathrm{L}$. Total phosphorus concentrations ranged from 0.10 to $6.4 \mathrm{mg} / \mathrm{L}$. No water-quality criteria exist for nutrient concentrations in wetlands in Minnesota or nationally, although the U.S. Environmental Protection Agency (USEPA) recently issued guidelines for developing wetland nutrient criteria (U.S. Environmental Protection Agency, 2007).

Most nutrient concentrations were greatest in the marshy wetlands 9 and 16, and particularly in wetland 9. Concentrations in wetland 9 decreased each year with increasing water levels in the wetland. For example, dissolved ammonia plus organic nitrogen concentrations decreased from 38.1 to 2.8 $\mathrm{mg} / \mathrm{L}$ over 3 years. Lower nutrient concentrations when the wetland had higher water levels were likely caused by dilution. The other two wetlands did not show temporal patterns during the 3 years of sampling. The open-water wetland (15) had the lowest concentrations of nutrients, likely because less vegetative matter was available for decay and mineralization of nutrients.

Other nutrients were rarely detected at concentrations equal to or greater than the LTMDL. These constituents include dissolved nitrite and nitrite plus nitrate.

\section{Bed-Sediment Quality}

Bed-sediment samples were collected from the three wetlands and analyzed for size distribution, metals, trace elements, and organic compounds, similar to streambed sediment. The composition of wetland samples was very different than those from Seguchie Creek (fig. 3B). Bed-sediment data for the sampled sites are available at http://nwis.waterdata.usgs. gov/mn/nwis/qwdata. 
Table 5. Estimated loading rates for dissolved chloride, selected nutrients, and suspended sediment in Seguchie Creek.

[Upper- and lower-95th percentile confidence intervals are presented in parentheses ( ) following loading rate values for annual- and study-period total loads for total phosphorus and suspended sediment, as part of the model output]

\begin{tabular}{|c|c|c|}
\hline \multicolumn{3}{|c|}{ Loading rates, by season (kilograms) } \\
\hline Season & $\begin{array}{c}\text { Upstream site } \\
\text { (05284305) }\end{array}$ & $\begin{array}{c}\text { Downstream site } \\
\text { (05284310) }\end{array}$ \\
\hline \multicolumn{3}{|c|}{ Dissolved chloride } \\
\hline Spring (May) 2004 & 163 & 198 \\
\hline Summer 2004 & 1,190 & 1,260 \\
\hline Fall 2004 & 2,260 & 2,390 \\
\hline Winter 2004 & 1,940 & 2,080 \\
\hline Spring 2005 & 3,930 & 4,000 \\
\hline Summer 2005 & 3,180 & 2,990 \\
\hline Fall 2005 & 4,520 & 4,400 \\
\hline Winter 2005 & 2,780 & 2,900 \\
\hline Spring 2006 & 3,500 & 3,730 \\
\hline Summer 2006 & 647 & 552 \\
\hline Fall (September) 2006 & .4 & 6.0 \\
\hline Total $^{1}$ for May to December 2004 & 4,260 & 4,550 \\
\hline Total $^{1}$ for 2005 & 14,100 & 14,000 \\
\hline Total $^{1}$ for January to September 2006 & 5,780 & 6,000 \\
\hline Total $^{1}$ for study (confidence intervals not available) & 24,100 & 24,500 \\
\hline \multicolumn{3}{|c|}{ Dissolved ammonia plus organic nitrogen } \\
\hline Spring (May) 2004 & 70 & 72 \\
\hline Summer 2004 & 515 & 546 \\
\hline Fall 2004 & 924 & 993 \\
\hline Winter 2004 & 749 & 676 \\
\hline Spring 2005 & 1,530 & 1,780 \\
\hline Summer 2005 & 1,250 & 1,440 \\
\hline Fall 2005 & 1,690 & 1,980 \\
\hline Winter 2005 & 1,010 & 1,100 \\
\hline Spring 2006 & 1,260 & 1,580 \\
\hline Summer 2006 & 243 & 236 \\
\hline Fall (September) 2006 & .1 & 1.1 \\
\hline Total $^{1}$ for May to December 2004 & 1,770 & 1,860 \\
\hline Total $^{1}$ for 2005 & 5,380 & 6,090 \\
\hline Total $^{1}$ for January to September 2006 & 2,090 & 2,450 \\
\hline Total $^{1}$ for study (confidence intervals not available) & 9,240 & 10,400 \\
\hline
\end{tabular}


Table 5. Estimated loading rates for dissolved chloride, selected nutrients, and suspended sediment in Seguchie Creek.-Continued

[Upper- and lower-95th percentile confidence intervals are presented in parentheses ( ) following loading rate values for annual- and study-period total loads for total phosphorus and suspended sediment, as part of the model output]

\begin{tabular}{|c|c|c|}
\hline \multicolumn{3}{|c|}{ Loading rates, by season (kilograms) } \\
\hline Season & Upstream site (05284305) & $\begin{array}{c}\text { Downstream site } \\
(05284310)\end{array}$ \\
\hline \multicolumn{3}{|c|}{ Total phosphorus } \\
\hline Spring (May) 2004 & 2 & 3 \\
\hline Summer 2004 & 16 & 28 \\
\hline Fall 2004 & 24 & 45 \\
\hline Winter 2004 & 17 & 24 \\
\hline Spring 2005 & 49 & 71 \\
\hline Summer 2005 & 45 & 76 \\
\hline Fall 2005 & 51 & 91 \\
\hline Winter 2005 & 26 & 39 \\
\hline Spring 2006 & 43 & 66 \\
\hline Summer 2006 & 9 & 13 \\
\hline Fall (September) 2006 & 0 & .1 \\
\hline Total $^{1}$ for May to December 2004 & $48(36-63)$ & $85(59-120)$ \\
\hline Total $^{1}$ for 2005 & $166(123-220)$ & $270(184-381)$ \\
\hline Total $^{1}$ for January to September 2006 & $67(51-87)$ & $101(71-140)$ \\
\hline Total $^{1}$ for study & $282(236-335)$ & $456(369-558)$ \\
\hline \multicolumn{3}{|c|}{ Suspended sediment } \\
\hline Spring (May) 2004 & 245 & 301 \\
\hline Summer 2004 & 1,790 & 2,480 \\
\hline Fall 2004 & 3,330 & 7,060 \\
\hline Winter 2004 & 2,770 & 2,870 \\
\hline Spring 2005 & 5,770 & 4,140 \\
\hline Summer 2005 & 4,780 & 5,120 \\
\hline Fall 2005 & 6,640 & 10,300 \\
\hline Winter 2005 & 4,060 & 3,560 \\
\hline Spring 2006 & 5,180 & 2,900 \\
\hline Summer 2006 & 1,010 & 634 \\
\hline Fall (September) 2006 & .4 & 8.0 \\
\hline Total $^{1}$ for May to December 2004 & $6,310(3,890-9,760)$ & $11,200(5,140-21,500)$ \\
\hline Total $^{1}$ for 2005 & $20,700(12,000-33,500)$ & $22,900(9,550-46,800)$ \\
\hline Total $^{1}$ for January to September 2006 & $8,600(5,320-13,200)$ & $5,290(2,200-10,800)$ \\
\hline Total $^{1}$ for study & $35,600(24,000-58,000)$ & $39,400(23,400-62,200)$ \\
\hline
\end{tabular}

${ }^{1}$ Figures may not sum to totals because of independent rounding. 


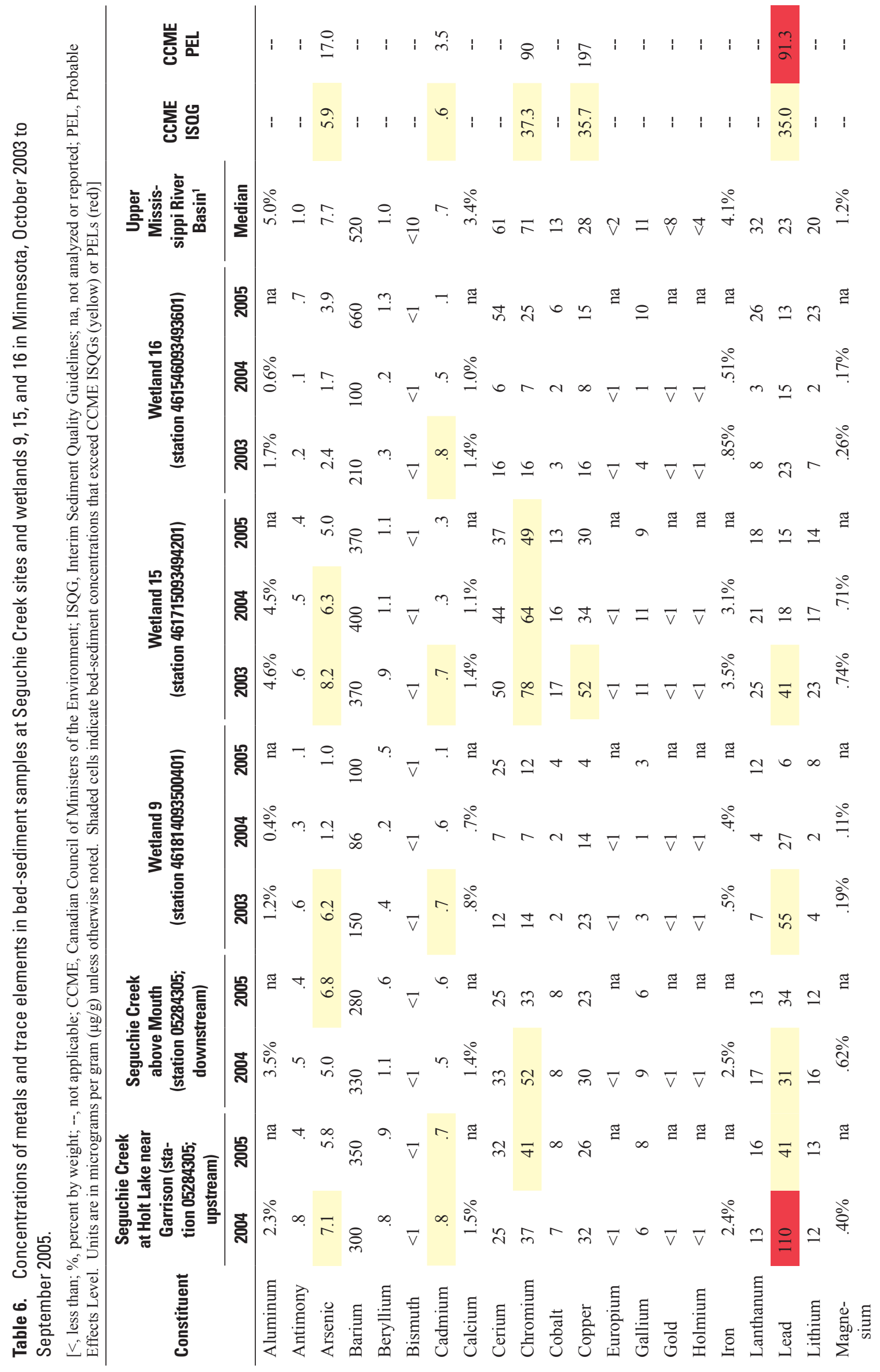




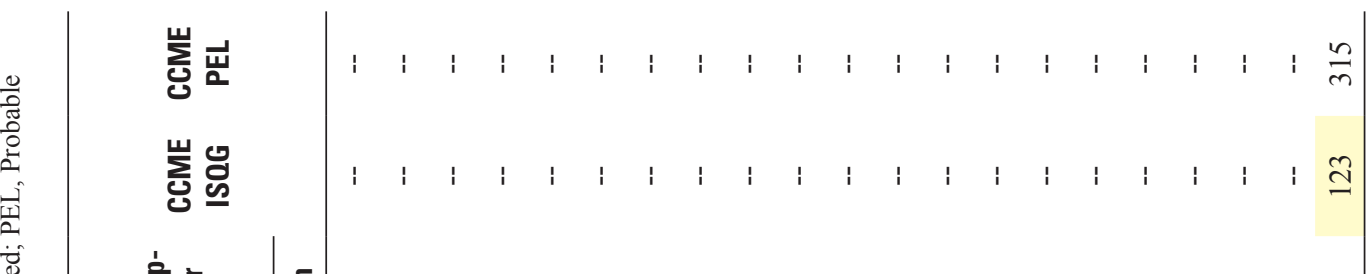

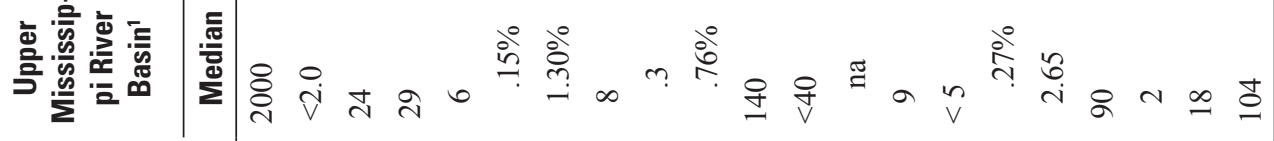

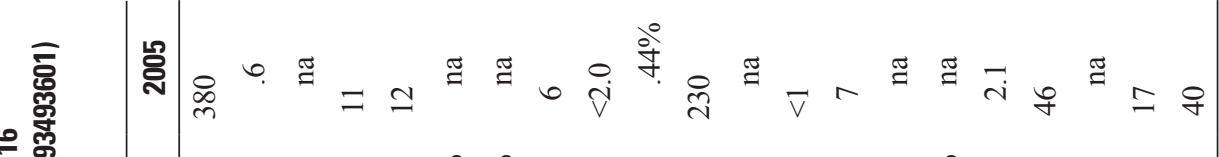
동

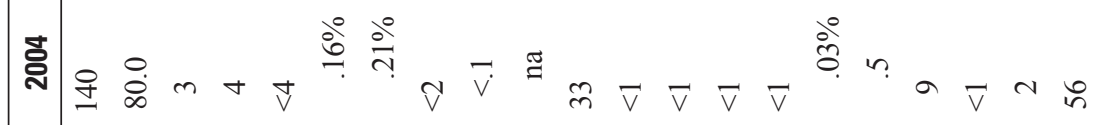
空

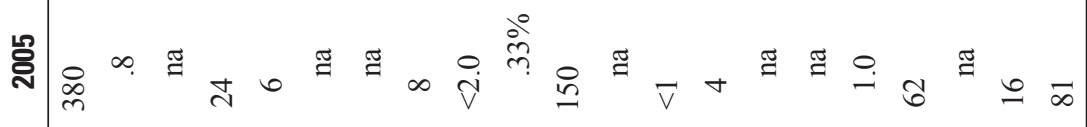
ปั

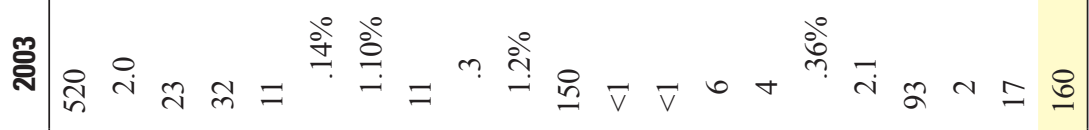

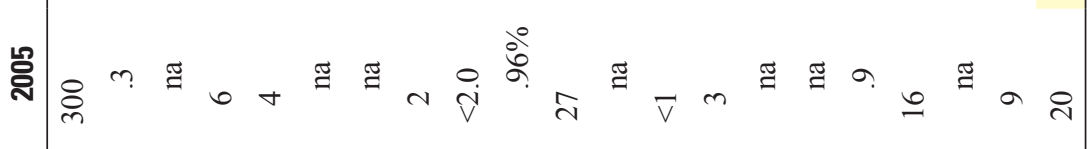

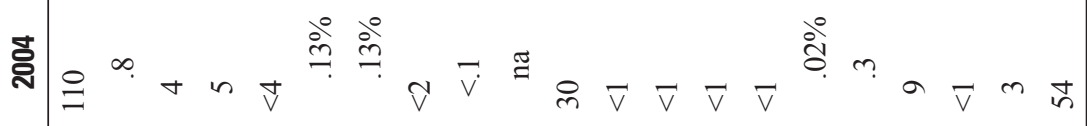
䓂

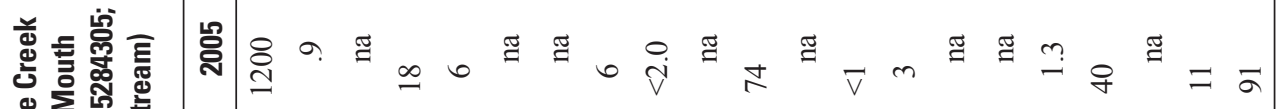

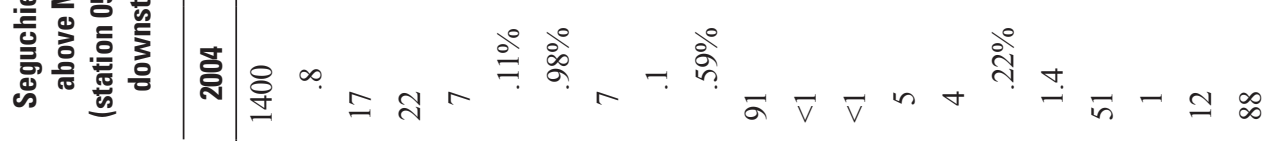

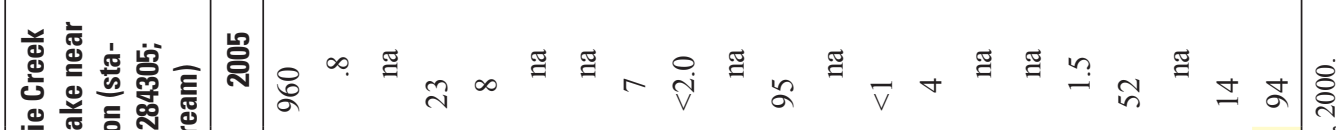

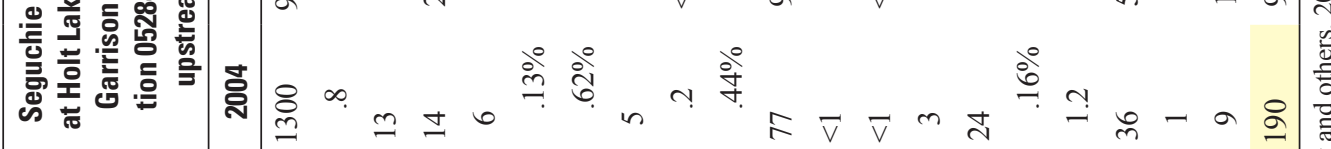

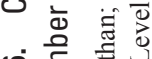




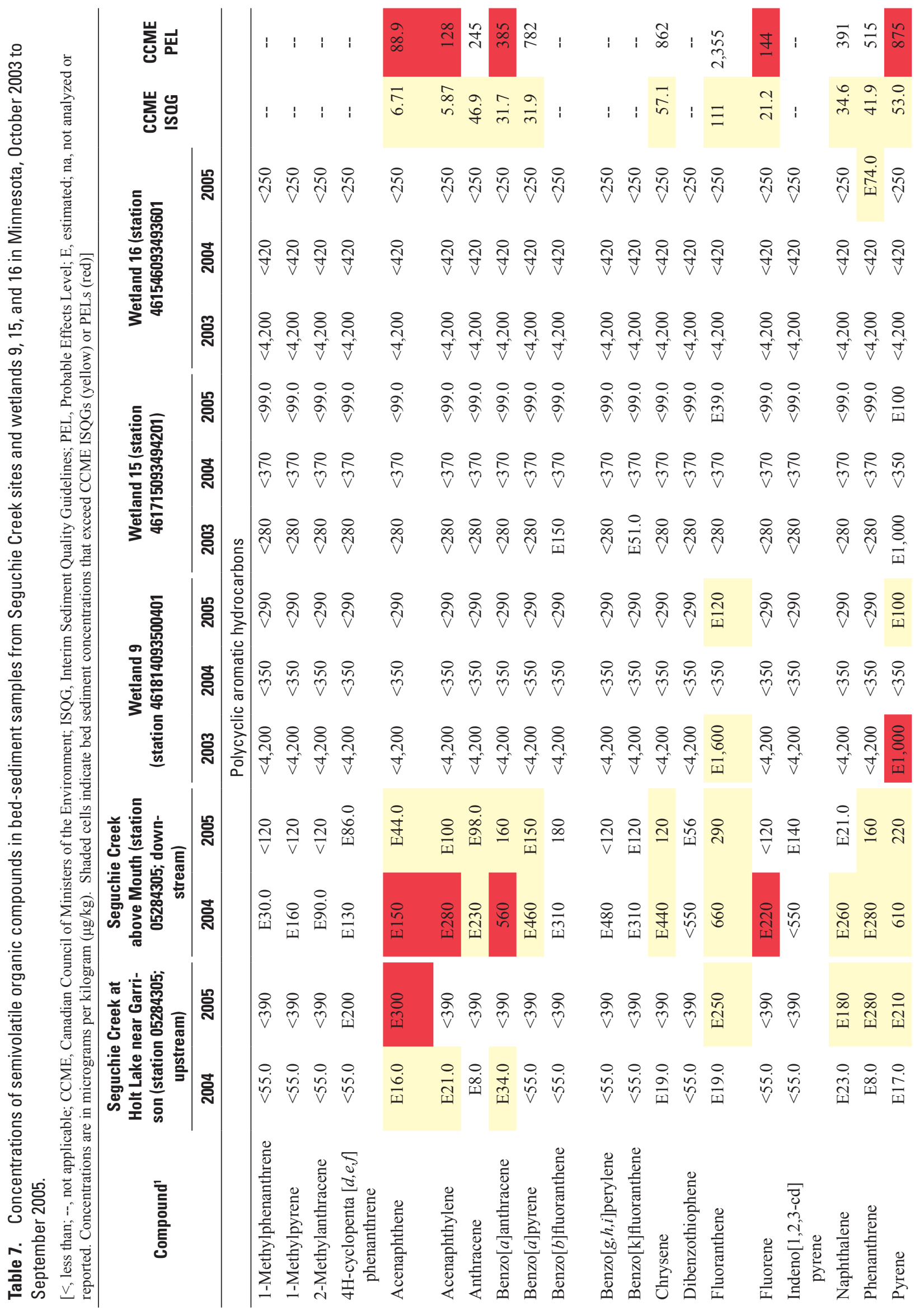




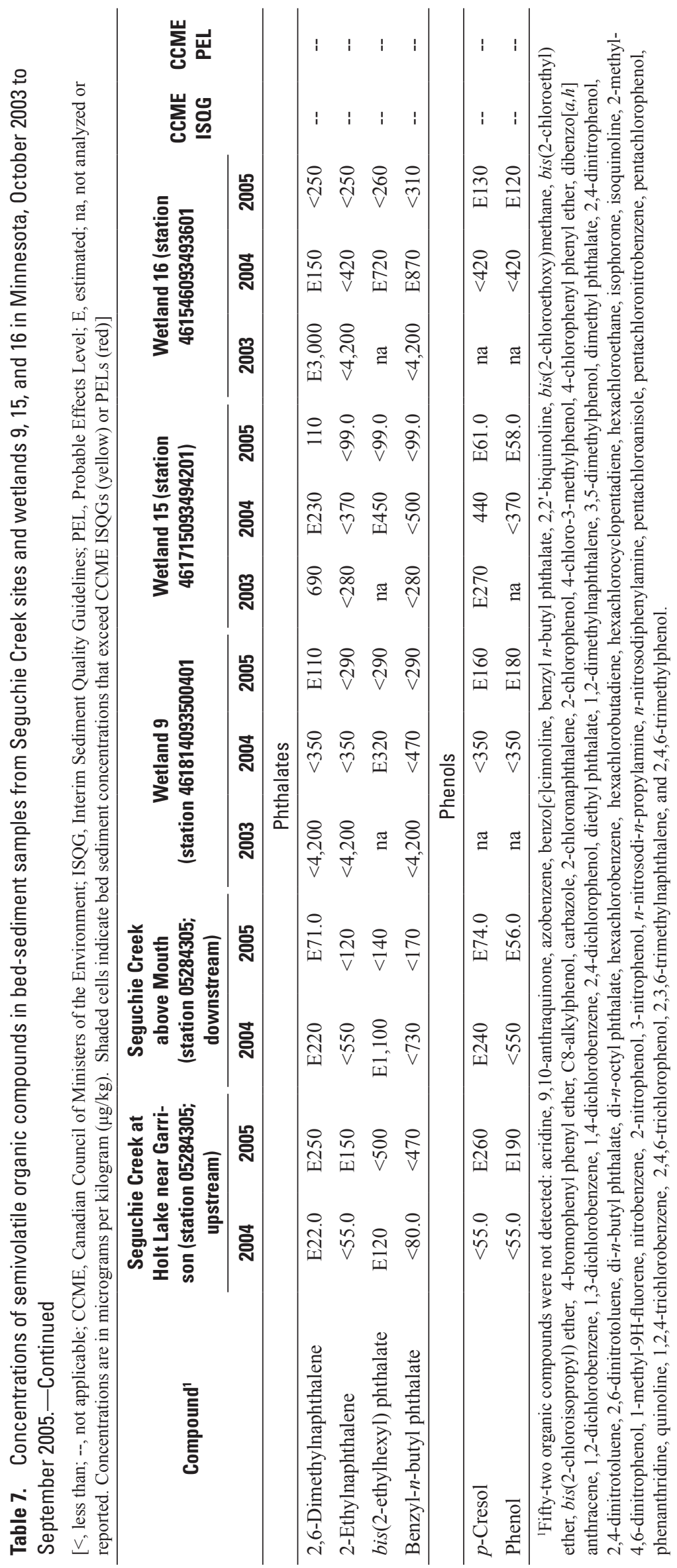




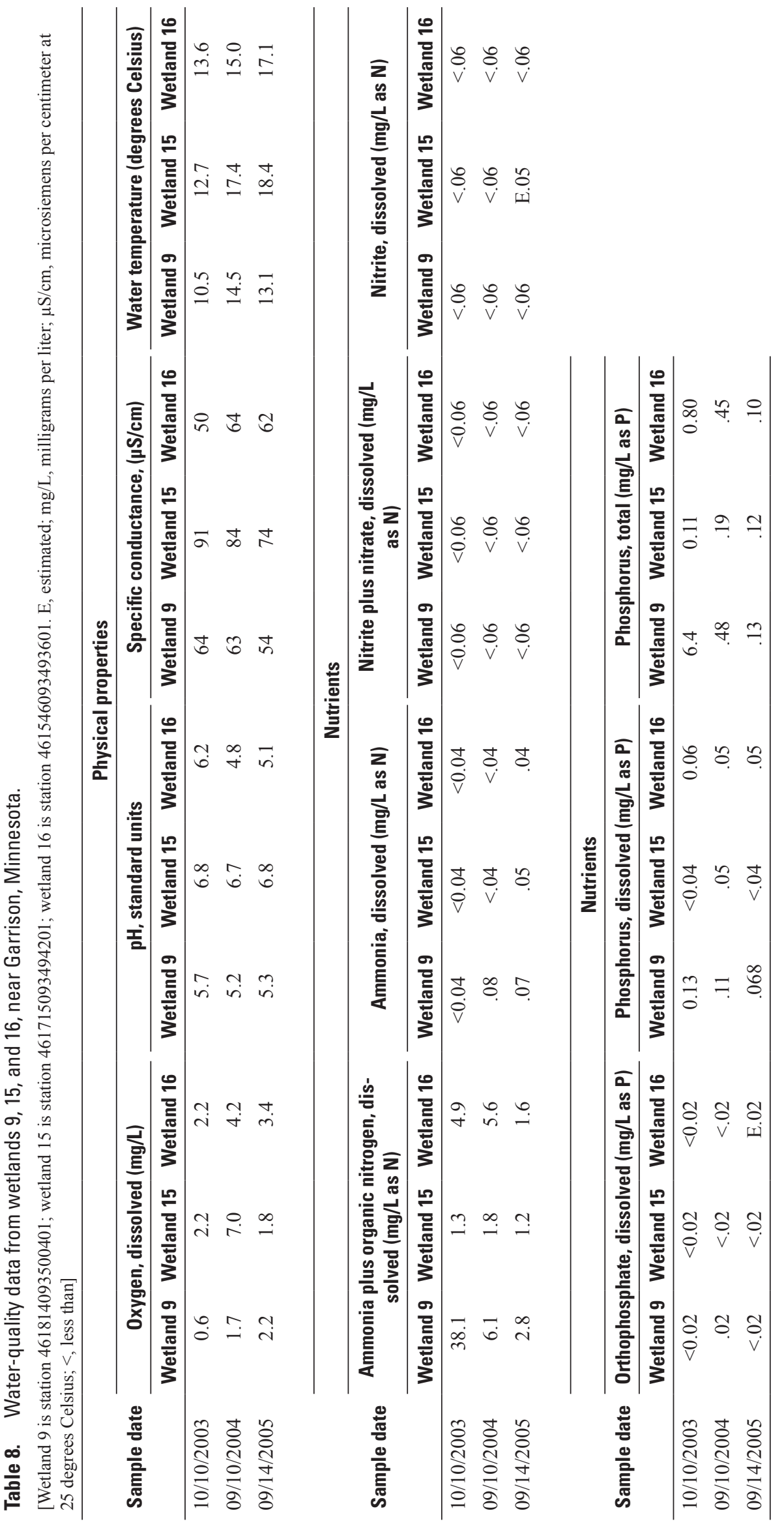




\section{Size}

Bed-sediment samples for particle-size analyses were collected each fall during 2003-05 for a total of three samples at each wetland. Particle-size analyses were complicated by the large proportion of organic matter in samples, which often resulted in incomplete analyses.

All sample particle sizes were less than $2 \mathrm{~mm}$ (fig. 4). Twenty-five to 60 percent of samples were composed of fine (silt- and clay-sized) particles (less than $0.063 \mathrm{~mm}$ ). Wetlands 9 and 16 had the greatest percentage of fine particles - approximately 50-60 percent. Wetland 15 had the greatest percentage of sand-sized particles $(0.063-2.0 \mathrm{~mm})$. Mean particle sizes of wetland samples were smaller than those from Seguchie Creek samples.

\section{Metals and Trace Elements}

Fine-grained bed-sediment samples from wetlands 9, 15, and 16 were collected during the fall seasons of 2003-05 and analyzed for metals and trace elements. Concentrations are presented in table 6 along with CCME guidelines (Canadian Council of Ministers of the Environment, 2002) and median concentrations of samples collected from the Upper Mississippi River Basin during 1995-96 (Kroening and others, 2000). ISQGs and PELs were not specifically designed for wetlands, but values serve as a reference. The USEPA considers numeric aquatic-life criteria to be generally applicable to most wetland types (U.S. Environmental Protection Agency, 1990).

Reported metal and trace element concentrations (table 6) varied from year to year for a given sampling site and constituent, and variability ranged from 0 to 13,200 percent with a median of 83 percent. Concentrations of all but three elements (lithium, molybdenum, and sodium) were within one order of magnitude for samples from all 3 years.

Samples from wetland 15 had the most exceedances of CCME ISQGs (nine) and the greatest concentrations of metals and trace elements, and samples from wetland 9 had the lowest concentrations. Concentrations of all six metals and trace elements with ISQGs exceeded the respective ISQGs in at least one sample: arsenic, cadmium, chromium, copper, lead, and zinc. Arsenic concentrations in the 2003 sample from wetland 9 and in the 2003 and 2004 samples from wetland 15 exceeded the ISQG of $5.9 \mu \mathrm{g} / \mathrm{g}$. Cadmium concentrations exceeded the $0.6 \mu \mathrm{g} / \mathrm{g}$ ISQG in the 2003 samples from all three wetlands. Chromium concentrations in all three samples from wetland 15 exceeded the ISQG of $37.3 \mu \mathrm{g} / \mathrm{g}$. Copper concentrations in the 2003 sample from wetland 15 exceeded the ISQG of 35.7 $\mu \mathrm{g} / \mathrm{g}$. Lead concentrations in the 2003 samples from wetlands 9 and 15 exceeded the ISQG of $35.0 \mu \mathrm{g} / \mathrm{g}$. Zinc concentrations in the 2003 sample from wetland 15 exceeded the ISQG of $123 \mu \mathrm{g} / \mathrm{g}$.

\section{Organic Compounds}

Ten of 87 semivolatile organic compounds were detected in wetlands (table 7) - far fewer than the 25 compounds detected in Seguchie Creek. Wetland 15 had the greatest number of compounds detected (eight). Six compounds were detected in samples from wetlands 9 and 16 .

Similar to metals and trace elements, reported concentrations of organic compounds varied from year to year for a given sampling site and compound. Most compounds were detected only once, but of those detected more often, concentrations frequently varied by one or slightly more orders of magnitude. Analytical uncertainty likely was a substantial cause of the variability, as evident by the varying reporting levels from year to year and the numerous estimated values.

Concentrations of three PAHs exceeded CCME ISQGs: flouranthene, phenanthrene, and pyrene (table 7), with most exceedances in samples from wetland 9. Flouranthene concentrations in the 2003 and 2005 samples from wetland 9 exceeded the ISQG of $111 \mu \mathrm{g} / \mathrm{kg}$. Concentrations of phenanthrene in the 2005 sample from wetland 16 exceeded the ISQG of $41.9 \mu \mathrm{g} / \mathrm{kg}$. Pyrene concentrations in the 2003 sample from wetland 9 exceeded not only the ISQG of $53.0 \mu \mathrm{g} / \mathrm{kg}$, but also the PEL of $875 \mu \mathrm{g} / \mathrm{kg}$; the pyrene concentration in the 2005 sample from wetland 9 also exceeded the ISQG. Other semivolatile organic compounds detected were the phthalates 2,6-dimethylnaphthalene, bis (2-ethylhexyl) phlalate, and benzyl- $n$-butyl phthalate, and the phenols $p$-cresol and phenol. All were detected in every wetland, except benzyl- $n$-butyl phthalate, which was detected only in wetland 16 .

\section{Implications of Study Findings}

Results of this study have implications for the water quality of tributaries to Mille Lacs Lake, for comparison with previous simulation results for the MNDOT, and for improvements of future monitoring. The water quality of Seguchie Creek generally was good with no concentrations exceeding the State of Minnesota water-quality standards with the exception of dissolved-oxygen concentrations.

However, water and bed-sediment quality have been affected, sometimes adversely, by human activities or natural processes. Many detected metals and organic compounds can be toxic to humans and aquatic organisms, are suspected or known human carcinogens, and may disrupt endocrine systems (Canadian Council of Ministers of the Environment, 1995; Kaltreider and others, 2001; Stoica and others, 2000; Telisman and others, 2000; U.S. Department of Health and Human Services, 2007). These constituents commonly are associated with roadway activities, but most sampling sites were located upstream or away from highways and roads. Consequently, other land-use activities or sources have affected the presence and distribution of these constituents in streams and wetlands. 
At the upstream Seguchie Creek site, concentrations of dissolved lead in two samples were three to five times greater than in any other samples. Similarly, seven of the nine exceedances of CCME ISQGs for metals and trace elements in bed sediment, including arsenic, cadmium, chromium, lead, and zinc, occurred at the upstream site. One lead concentration at the upstream site exceeded the PEL. These compounds commonly are detected in roadway runoff; in roadway runoff in the Twin Cities metropolitan area, the constituents with the greatest concentrations were lead, copper, zinc, aluminum, and chromium (Mitton and Payne, 1996). Similar findings, with the addition of cadmium, have been found by others (Davis and others, 2001; Legret and Pagotto, 1999). Vehicle tire wear can contribute zinc (Davis and others, 2001). However, no highways, roadways, or known natural sources of lead exist near the upstream Seguchie Creek sampling site, so bed-sediment quality likely has been affected by other activities.

In addition to highway activities, other sources can contribute to the presence of these constituents in water and bed sediment. Metals and trace elements, including arsenic and related compounds, are used in wood preservatives, pesticides, manufacturing, smelting, and other industrial activities. Cadmium is used in metal coatings, batteries, plastic, and pigment manufacturing (U.S. National Library of Medicine, 2006). Chromium is used in steel production, chrome plating, dyes, pigments, leather tanning, wood preserving, and combustion of coal, oil, and natural gas (U.S. National Library of Medicine, 2006). Zinc and related compounds are used in mining, refining, die casting, and manufacturing of steel, fertilizer, rubber, and paint. Tin and related compounds can be released through use of pesticides, paints, food container liners, and fishing tackle (U.S. Department of Health and Human Services, 2007). Lead is refined for alloys, batteries, ammunition, paints, and ceramics (U.S. Department of Health and Human Services, 2007). In Minnesota, lead shotgun pellets can be used for recreational hunting, but their use for hunting water fowl was banned nationwide in 1991 (Friend and Franson, 1999). The Minnesota Pollution Control Agency estimates that ammunition is the single largest source of lead to the environment in Minnesota, even though use has been banned for waterfowl hunting in Minnesota since 1987 (Minnesota Pollution Control Agency, 1999). In addition, lead commonly is used in fishing lures and weights in Minnesota, although less toxic, replacement metals and compounds are encouraged (Minnesota Pollution Control Agency, 2007).

Conversely, most exceedances of ISQGs for organic compounds ( 20 of 28 exceedances) in bed sediment occurred at the downstream site on Seguchie Creek, indicating different sources of organic compounds than for metals. Of the two samples that were collected upstream and downstream from the reach with cabins at the downstream site, concentrations of all 11 PAHs that exceeded ISQGs were greater in the sample collected downstream from the cabins than the sample collected upstream from the cabins. Sources in the study area are unknown, but Verschueren (1983) compiled common sources of PAHs and other organic compounds: PAHs are found in hydrocarbon fuels, asphalts, tar, parking lot sealants, and incompletely combusted wood. PAHs occur naturally from the incomplete combustion of fuels in wildfires and volcanoes, and anthropogenic sources can increase concentrations. PAHs can be byproducts in paper production, petroleum refining, fossil fuel power generation, (Khalili and others, 1995) and reformulation of asphalt, coal, and tar. Products produced using PAHs include creosote for wood preservation, pesticides, fertilizers, medicines, dyes, plastics, and lubricants (Verschueren, 1983). PAHs commonly are present in large concentrations in asphalt sealants (Mahler and others, 2005). Other sources of PAHs include cooking, smoking, recreational fires, prescribed burns, waste incineration, and combustion of carbon fuels for home heating and motor vehicles (Verschueren, 1983). Phthalates commonly are used in plastics and emulsifiers (Verschueren, 1983). Phenols commonly are used in detergents, disinfectants, adhesives, preservatives, and for manufacturing (Verschueren, 1983).

Also at the downstream site, concentrations of dissolved cobalt and magnesium in water samples collected downstream from the cabin-lined reach were significantly greater $(\mathrm{p}<0.05$, Wilcoxon rank-sum test) than those collected upstream. Although concentrations of dissolved nickel and zinc were significantly greater $(p<0.05$, Wilcoxon rank-sum test $)$ in the reach upstream from the cabins, all samples at the downstream site were collected upstream from the current highway and service road bridges. These results indicate that previous landuse practices associated with the reach lined with cabins possibly contributed to the metal and trace element concentrations.

Natural wetland processes and groundwater interactions between sampling sites on Seguchie Creek also affected the water chemistry. Fifteen of 21 constituents sampled or measured had greater variability downstream than upstream. In addition, continuous specific conductance varied over a greater range and changed at a greater rate downstream than upstream in response to dry or wet periods and reflected changes that occurred in the chemistry of major ions. Although the well-mixed outflow from Holt Lake maintained relatively steady specific conductance values and water concentrations at the upstream site, wetland processes and interaction with groundwater at low flow had more influence on the basic water chemistry of the downstream site. Increases in specific conductance values and major ion concentrations commonly occurred during base flow because groundwater, enriched in ions from the dissolution of minerals in soils and aquifers (Hem, 1992), contributed relatively more water to the stream than the lake outflow, which occasionally experienced no-flow conditions. The greatest concentrations in dissolved major ions were observed during low flow. During wet periods, Seguchie Creek at the downstream site became slightly more diluted with precipitation and overland runoff and had lower specific conductance than the well-mixed lake outflow.

Wetland processes between monitoring sites may have affected concentrations of dissolved oxygen, manganese, and iron. Dissolved-oxygen concentrations were less than the Minnesota water-quality standard daily minimum of $4.0 \mathrm{mg} / \mathrm{L}$ 
(Minnesota Office of the Revisor of Statutes, 2007) for 6 of 26 measurements. Dissolved-oxygen concentrations generally were less at the downstream site (median concentrations were $9.4 \mathrm{mg} / \mathrm{L}$ upstream and $8.6 \mathrm{mg} / \mathrm{L}$ downstream; 25 th- percentile concentrations were $7.8 \mathrm{mg} / \mathrm{L}$ upstream and $4.5 \mathrm{mg} / \mathrm{L}$ downstream). Decomposition of organic material in wetlands can cause decreases in dissolved-oxygen concentrations. Dissolved manganese and iron concentrations generally increased with decreasing dissolved-oxygen concentration, and increases may have resulted from decreases in dissolved-oxygen concentrations. Dissolved manganese concentrations generally are low in well-oxygenated waters because the oxidized particulate form $\left(\mathrm{Mn}^{3+}\right)$ dominates, but in anoxic waters these manganese precipitates can be reduced to a soluble state $\left(\mathrm{Mn}^{2+}\right.$; Wetzel, 2001). Iron can behave similarly.

Natural variability affected loading rates. All four constituents (dissolved chloride, ammonia plus organic nitrogen, total phosphorus, and suspended sediment) had seasonal peaks in spring and fall. Although peaks in loads are typical during spring, occurring with peak streamflow from snowmelt, the large loads during fall were augmented by atypical streamflow trends during the study. Fall generally is a season of decreasing variability and rates of streamflow in Minnesota, but during this study the two greatest streamflow peaks at both sites occurred during October 2004 and 2005 (fig. 2). The October 2005 streamflow peak coincided with the greatest loads for all four constituents. In addition, peak flows during fall likely augmented the flush in organic matter from the wetland to the downstream site. During fall senescence, riparian, wetland, and other vegetation decompose and are transported by streamflow.

Atypical streamflow trends and channel characteristics at sampling locations may have affected streambed sediment particle-size distributions. Upstream samples were collected from a poorly defined channel through the wetland immediately downstream from the lake outflow where velocities slowed. Samples from the downstream site were collected first from a pool near the gage and then, beginning May 2005, from a defined channel where stream velocities were faster than at the upstream site. These faster velocities for the samples collected after May 2005 inhibited deposition of smaller particles, resulting in a particle-size distribution with a greater proportion of larger sediments. Similarly, considering only samples from the downstream reach, the mean particle size increased when sampling was moved from the pool near the gage with slow velocities in May 2005 to the channel farther upstream with faster velocities. Streamflow rates also may have affected particle-size distributions. At the upstream site, particle sizes of samples collected during the fall generally were greater than those from the spring. Two of the fall samples were collected during wet periods when streamflow was greater than that occurring during any of the spring sample collections, consequently stream energy was greater. No seasonal pattern was observed at the downstream site, probably because moving the sampling location from a pool to a channel confounded seasonal patterns.
In bed-sediment samples from wetlands, concentrations of at least one metal or trace element exceeded CCME ISQGs at each wetland. Samples from wetland 15 had the most exceedances and the greatest concentrations. This wetland, rated a potentially high-quality, shallow open-water wetland, capable of supporting wild rice beds, is not located near a road, so metal concentrations likely are because of previous land uses. Wetland 15 is located on the grounds of a 1930's Civilian Conservation Corps camp (John Mackner, Minnesota Department of Transportation, oral commun., 2005; Minnesota Department of Transportation, 1998). Sources of metals may be from waste deposited in or near the wetland in past years.

Wetland 9 had the most exceendances of ISQGs for semivolatile organic compounds in bed sediment (four exceedances), followed by wetland 16 (one exceedance). Sources of PAHs in wetland 9 are unknown. The wetland appeared relatively undisturbed and isolated with limited access and sparse rural housing nearby. It is possible that activities associated with an abandoned highway located approximately $50-100 \mathrm{~m}$ east of the wetland sampling locations may have contributed organic compounds in previous years. Nevertheless, these results indicate that even areas appearing relatively undisturbed and rated as high resource value can suffer degradation from previous, often unknown land uses.

A comparison of streamflow and loading rates made during this study with those made for the MNDOT in 2001 (Curt Eastlund, Minnesota Department of Transportation, written commun., 2003) found generally similar results. One difference was that streamflow measured in this study did not have equivalent responses to precipitation as the water budgets simulated for the MNDOT in 2001. The streamflow measured during this study in 2006 was 18 percent less than the simulated streamflow even though precipitation was 5 percent greater than simulated precipitation. Conversely, partial years of streamflow measured during this study had greater streamflow than simulated years even though simulated precipitation was greater. This indicates that the contributing storage volumes of Holt and Borden Lakes, upstream from where flow was simulated or gaged, have a large moderating and attenuating effect on streamflow. Other streams in the study area could be expected to have similar results.

Differences in streamflow between this study and the 2001 water-budget simulations did not substantially affect estimated phosphorus loading rates. Phosphorus loading rates for this study were about 1.5 times less than those simulated for the MNDOT in 2001 (Curt Eastlund, Minnesota Department of Transportation, written commun., 2003), for roughly similar precipitation amounts. These differences likely are within the uncertainties associated with the calculations.

Modifications to the approach used in this study might improve efficiencies or comparisons should investigations continue at a later date. The low-gradient and large storage characteristics of Seguchie Creek resulted in streamflow, constituent concentrations, and loading rates that did not change substantially during runoff events. Other streams draining to Mille Lacs Lake have similar physical characteristics and 
would likely respond similarly. Although these characteristics could change with the addition of highway construction, future studies would benefit from the use of well-timed synoptic sampling events to increase the knowledge of loading from other streams intersecting the proposed highway route. Synoptic studies could be conducted during snowmelt and the days following large rainfall events when the greatest increases in loading rates would be anticipated. These samples could be compared to the continuously monitored data from Seguchie Creek, if still active, for reference.

It is unclear to what extent the slightly greater drainage area and streamflow rates of the downstream site affected the increases observed in loads in Seguchie Creek. Chloride is generally a conservative constituent, and the slight to insignificant increase in chloride concentrations (within the error of analytical estimates) between the upstream and downstream sites indicates that increases in downstream streamflow may not be a factor. Furthermore, nitrogen, phosphorus, and suspended sediment commonly are contributed by decaying organic matter in wetlands, so downstream increases in these constituents may indicate these constituents simply are being exported from the intermediate wetland. Nevertheless, if future studies compare loads upstream and downstream from the proposed highway in this stream reach, sampling immediately above and below the construction area may be more important than obtaining accurate streamflow from both locations. The downstream gage may be the only site needed unless the highway design includes plans for routing additional drainage area to Seguchie Creek.

Similarly, the greater concentrations of dissolved manganese and iron found at the downstream site may have resulted from decreases in dissolved-oxygen concentrations as water flowed through the wetland located between the monitoring sites. Additionally, bed-sediment particle-size analyses indicate that size distribution is dependent upon streamflow velocities, which in turn, are dependent on streamflow rates and channel configurations. If future investigation includes monitoring Seguchie Creek upstream and downstream from the proposed construction area for these constituents, more comparable results may be obtained by sampling immediately upstream and downstream from the construction in reaches that are physically similar.

\section{Summary}

Mille Lacs Lake and its tributaries, located in east-central Minnesota, are important resources to the public. In addition, many wetlands and lakes that feed Mille Lacs Lake are of high resource quality and vulnerable to degradation. Construction of a new four-lane expansion of U.S. Highway 169 has been planned along the western part of the drainage area of Mille Lacs Lake in Crow Wing County. Concerns exist that the proposed highway could affect the resource quality of surface waters tributary to Mille Lacs Lake, which is sensitive to eutrophication from nutrient loads. Many tributary wetlands are of high resource quality, supporting wild rice beds, feeding streams, and providing habitat for keystone wildlife species. Baseline water- and bed-sediment quality characteristics of surface waters tributary to Mille Lacs Lake prior to the proposed highway construction were needed. Water-quality data collected prior to construction can be used to compare with data from future studies to evaluate the effectiveness of newer construction best management practices designed to minimize the effects of highway runoff and to assess the effects of associated changes in land use on water quality. The U.S. Geological Survey, in cooperation with the Minnesota Department of Transportation (MNDOT), characterized the water- and bed-sediment quality from October 2003 to October 2006 for Seguchie Creek upstream and downstream from the proposed route and for three wetlands draining to Mille Lacs Lake that the proposed route intersects.

In Seguchie Creek, the mean streamflow at the downstream gaging station of 0.22 cubic meter per second $\left(\mathrm{m}^{3} / \mathrm{s}\right)$ was 5.6 percent greater than streamflow at the upstream gaging station of $0.21 \mathrm{~m}^{3} / \mathrm{s}$. The greater streamflow at the downstream gaging station may have resulted from the 3.5 percent greater drainage area of this gaging station. Because of the large amount of storage immediately upstream from both gaging stations, increases in flow were gradual even during intense precipitation.

Seguchie Creek was sampled at two sites near the gaging stations for chemical constituents that frequently are associated with highway construction and operation. The ranges of most constituent concentrations in water were nearly identical between the sites. Concentrations generally were low, and no constituent concentrations exceeded applicable water-quality standards set by the State of Minnesota. However, dissolvedoxygen concentrations at the downstream site were less than the daily minimum of 4.0 milligrams per liter $(\mathrm{mg} / \mathrm{L})$ for 6 of 26 measurements. At the upstream site, concentrations of dissolved lead in two water samples were three to five times greater than lead concentrations in other samples.

Loads, computed for dissolved chloride, dissolved ammonia plus organic nitrogen, total phosphorus, and suspended sediment were 1.7 to 62 percent greater at the downstream site than at the upstream site. All constituents had seasonal peaks in spring and fall. The large loads during fall were augmented by atypical streamflow trends during the study when the two greatest streamflow peaks at both sites occurred during October 2004 and 2005.

In bed-sediment samples from Seguchie Creek, more exceedances of Interim Sediment Quality Guidelines (ISQG) set by the Canadian Council of Ministers of the Environment for metals and trace elements, including lead, occurred at the upstream site (seven) than the downstream site (two). Concentrations of 5 of the 6 metals and trace elements (arsenic, cadmium, chromium, lead, and zinc) exceeded the corresponding ISQGs in at least one bed-sediment sample from Seguchie Creek. Because no highways, roadways, or known natural 
sources of lead occur near this sampling site, bed-sediment quality has been affected by other activities.

The downstream site had more exceedances of ISQGs than the upstream site for semivolatile organic compounds (20 of 20 exceedances) in bed sediment indicating different sources for organic compounds than for metals and trace elements. In 2005, the sampling location at the downstream site was moved farther upstream to limit potential influence from cabins near the stream. Concentrations of all 11 PAHs that exceeded ISQGs - ancenaphthene, acenaphthylene, anthracene, benzo $[a]$ anthracene, benzo $[a]$ pyrene, chrysene, fluoranthene, fluorene, naphthalene, phenanthrene, and pyrene-were greater in the sample collected downstream from the cabins than the sample collected upstream from them, indicating possible sources from previous activities in this reach. Similarly, concentrations of dissolved cobalt and magnesium in samples collected downstream from the reach with cabins were significantly greater than those collected immediately upstream, although concentrations of dissolved nickel and zinc were greater upstream $(\mathrm{p}<0.05)$ from the reach with cabins.

Three water samples from each of the wetlands were collected for analysis of nutrients. Most nutrient concentrations were greatest in the two marshy wetlands sampled. The open-water wetland had the lowest concentrations of nutrients, likely because less vegetative matter was available for decay and mineralization of nutrients.

In bed-sediment samples from wetlands, concentrations of six metals and trace elements exceeded ISQGs: arsenic, cadmium, chromium, copper, lead, and zinc. Each wetland had concentrations of at least one metal or trace element that exceeded ISQGs. Wetland 15, located on the grounds of a 1930's Civilian Conservation Corps camp, had the most exceedances (9) of ISQGs for metrals and trace elements. Concentrations of three semivolatile organic compounds exceeded ISQGs: flouranthene, phenanthrene, and pyrene. Wetland 9, located adjacent to an abandoned highway had the most exceedances of ISQGs for semivolatile organic compounds (four). Results indicate that areas appearing relatively undisturbed and of high resource value can have degraded water quality from previous, unknown land use.

Although the water quality of Seguchie Creek generally was good, the water and bed-sediment quality likely has been affected by human activities and natural processes. Furthermore, although many constituents detected in water or with concentrations that exceed bed-sediment quality guidelines are commonly associated with roadway activities, most sampling sites were located upstream or away from roadways. Natural wetland processes and groundwater interactions between sampling sites on Seguchie Creek also affected water chemistry. Fifteen of 21 constituents sampled or measured in water samples had greater variability downstream than upstream. Similarly, continuous specific conductance varied over a greater range and changed at a greater rate downstream than upstream in response to dry or wet periods and reflected changes that occurred in the chemistry of major ions. The well-mixed outflow from Holt Lake maintained relatively steady specific conductance and water chemistry at the upstream site, whereas wetland processes, interaction with groundwater at low flow, and runoff during heavy precipitation, influenced basic water chemistry of the downstream site.

Wetland processes between sampling sites on Seguchie Creek likely affected concentrations of dissolved oxygen, manganese, and iron. Decomposition of organic material in wetlands can decrease dissolved-oxygen concentrations. Increases in dissolved manganese and iron concentrations can result from decreases in dissolved-oxygen concentrations, as these manganese and iron precipitates can be reduced to a soluble state in anoxic waters.

A comparison of streamflow and loading rates between this study and simulations for the MNDOT in 2001 generally showed similar results. One difference was that streamflow measured in this study did not have equivalent responses to precipitation as the water budgets simulated for the MNDOT in 2001, which indicates that the contributing storage volumes of upstream lakes have a large moderating and attenuating effect on streamflow. Phosphorus loading rates for this study were about 1.5 times less than those simulated for the MNDOT in 2001, for roughly similar precipitation amounts.

Modifications to the approach used in this study might improve efficiencies or comparisons should investigation continue at a later date. Future studies would benefit from the use of well-timed synoptic sampling events to increase the knowledge of loading from other streams intersecting the proposed highway route. Synoptic studies could be conducted during snowmelt and the days following large rainfall events.

If future studies compare loads upstream and downstream from the proposed highway in Seguchie Creek, sampling immediately upstream and downstream from the construction area may be more important than obtaining accurate streamflow from both locations. The downstream gaging station may be the only site needed unless the highway design includes plans for routing additional drainage area to Seguchie Creek.

\section{References Cited}

\author{
Albert, D.A., 1995, Regional landscape ecosystems of \\ Michigan, Minnesota, and Wisconsin - a working map \\ and classification: U.S. Department of Agriculture, Forest \\ Service General Technical Report NC-178: Northern Prairie \\ Wildlife Research Center Online, accessed November 14, \\ 2007, at http://www.npwrc.usgs.gov/resource/habitat/rland- \\ scp/index.htm.
}

Bricker, O.P., 1999, An overview of the factors involved in evaluating the geochemical effects of highway runoff on the environment: U.S. Geological Open-File Report 98-630, $29 \mathrm{p}$. 
Briggs, P.H., and Meier, A.L., 1999, The determination of 42 elements in geological materials by inductively coupled plasma mass spectrometry: U.S. Geological Survey OpenFile Report 99-166, 15 p.

Buchanan, T.J., and Somers, W.P., 1969, Discharge measurements at gaging stations: U.S. Geological Survey Techniques for Water Resources Investigations, book 3, chap. A8, $65 \mathrm{p}$.

Canadian Council of Ministers of the Environment, 1995, Protocol for the derivation of Canadian sediment quality guidelines for the protection of aquatic life, CCME EPC98E: Ottawa, Canada, Environment Canada, Guidelines Division, Technical Secretariat of the CCME Task Group on Water Quality Guidelines [Reprinted in Canadian environmental quality guidelines, Chapter 6, Canadian Council of Ministers of the Environment, 1999, Winnipeg], 35 p.

Canadian Council of Ministers of the Environment, 2002, Canadian sediment quality guidelines for the protection of aquatic life - summary tables, updated in Canadian environmental quality guidelines, 1999: Winnipeg, Canada, Canadian Council of Ministers of the Environment, 7 p.

Childress, C.J.O., Foreman, W.T., Connor, B.F., and Maloney, T.J., 1999, New reporting procedures based on longterm method detection levels and some considerations for interpretations of water-quality data provided by the U.S. Geological Survey National Water Quality Laboratory: U.S. Geological Survey Open-File Report 99-193, 19 p.

Cowardin, L.M., Carter, V., Golet, F.C., and LaRoe, E.T., 1979, Classifications of wetlands and deepwater habitats of the United States: U.S. Fish and Wildlife Service Report OBS-79/31, $142 \mathrm{p}$.

Davis A.P., Shokouhian, M., and Ni, S., 2001, Loading estimates of lead, copper, cadmium, and zinc in urban runoff from specific sources: Chemosphere, v. 44 , no. 5 , p. $997-1,009$.

Davidian, Jacob, and Carter, R.W., 1968, General procedure for gaging streams: U.S. Geological Survey Techniques of Water-Resources Investigations, book 3, chap. A6, 13 p.

Fallon, J.D., and McNellis, R.P., 2000, Nutrients and suspended sediment in snowmelt runoff from part of the Upper Mississippi River Basin, Minnesota and Wisconsin, 1997: U.S. Geological Survey Water-Resources Investigations Report 00-4165, 23 p.

Fallon, J.D., Arvin, D.V., Arntson, A.D., Guttormson, K.G., Mitton, G.B., and Wakeman, E.S., 2004, Surface-water quality assurance plan for the Minnesota District of the U.S. Geological Survey: U.S. Geological Survey Open-File Report 02-220, 43 p.
Fishman, M.J., ed., 1993, Methods of analysis by the U.S. Geological Survey National Water Quality Laboratorydetermination of inorganic and organic constituents in water and fluvial sediments: U.S. Geological Survey Open-File Report 93-125, $217 \mathrm{p}$.

Fishman, M.J., and Friedman, L.C., 1989, Methods for determination of inorganic substances in water and fluvial sediments: U.S. Geological Survey Techniques of WaterResources Investigations, book 5, chap. A1, 545 p.

Friend, M., and Franson, J.C., eds, 1999, Lead, in Field manual of wildlife diseases - general field procedures and diseases of birds: U.S. Geological Survey, Information and Technology Report 1999-001, 426 p.

Furlong, E.T., Vaught, D.G., Merten, L.M., Foreman, W.T., and Gates, P.M., 1996, Methods of analysis by the U.S. Geological Survey National Water Quality Laboratorydetermination of semivolatile organic compounds in bottom sediment by solvent extraction, gel permeation chromatographic fractionation, and capillary-column gas chromatography/mass spectrometry: U.S. Geological Survey OpenFile Report 95-719, 67 p.

Garbarino, J.R., Kanagy, L.K., and Cree, M.E., 2006, Determination of elements in natural-water, biota, sediment and soil samples using collision/reaction cell inductively coupled plasma-mass spectrometry: U.S. Geological Survey Techniques and Methods, book 5, sec. B, chap.1, 88 p.

Ging, P.B., 1999, Water-quality assessment of south-central Texas - comparison of water quality in surface-water samples collected manually and by automated samplers: U.S. Geological Survey Fact Sheet FS-172-99, 6 p.

Gjessing, E., Lygren, E., Berglind, L., Gulbrandsen, T., and Skaane, R., 1984, Effect of highway runoff on lake water quality: Science of the Total Environment, v. 33, p. $245-257$.

Granato, G.E., and Smith, P.K., 1999, Estimating concentrations of road-salt constituents in highway-runoff from measurements of specific conductance: U.S. Geological Survey Water-Resources Investigations Report 99-4077, 22 p.

Great Lakes Indian Fish and Wildlife Commission, 2004, Masina'igan - a chronicle of the Lake Superior Ojibwe, Mille Lacs Lake modeling supplement, accessed February 16, 2007, at http://www.glifwc.org/publications/mazinaigan/ MilleLacs_Supplement.pdf, 8 p.

Guy, H.P., 1977, Laboratory theory and methods for sediment analysis: U.S. Geological Survey Techniques of WaterResources Investigations, book 5, chap C1, $58 \mathrm{p}$.

Heiskary, S., Koser, J., and Hodgson, J., 1994, Lake Mille Lacs 1992: Minnesota Pollution Control Agency Clean Lakes Study (314a) Water Quality Report, 105 p. 
Hem, J.D., 1992, Study and interpretation of the chemical characteristics of natural water: U.S. Geological Survey Water-Supply Paper 2254, 263 p.

Kaltreider, R.C., Davis, A.M., Lariviere, J.P., and Hamilton, J.W., 2001, Arsenic alters the function of the glucocorticoid receptor as a transcription factor: Environmental Health Perspectives, v. 109, p. 245-251.

Khalili, N.R., Scheff, P.A., and Holsen, T.M., 1995, PAH source fingerprints for coke ovens, diesel and gasoline engines, highway tunnels, and wood combustion emissions: Atmospheric Environment, v. 29, no. 4, p. 533-542.

Kroening, S.E., Fallon, J.D., and Lee, K.E., 2000, Water-quality assessment of part of the Upper Mississippi River Basin, Minnesota and Wisconsin - trace elements in streambed sediment and fish livers, 1995-96: U.S. Geological Survey Water-Resources Investigations Report 00-4031, 26 p.

Kroening, S.E., Lee, K.E., and Goldstein, R.M., 2003, Waterquality assessment of part of the Upper Mississippi River Basin, Minnesota and Wisconsin — nutrients, chlorophyll $a$, phytoplankton, and suspended sediment in streams, 199698: U.S. Geological Survey Water-Resources Investigations Report 02-4287, 34 p.

Lamers, L.P.M., Edyta, S.J.F., Samborska, M., van Dulken, I.A.R., van Hengstum, G., and Lamers, J.G., 2002, Factors controlling the extent of eutrophication and toxicity in sulfate-polluted freshwater wetlands: Limnology and Oceanography, v. 47, no. 2, p. 585-593.

Legret, M., and Pagotto, C., 1999, Evaluation of pollutant loadings in the runoff waters from a major rural highway in Baveno, Harrison, R.M., Hamilton, R.S., eds., International Symposium on Highway and Urban Pollution: Science of the Total Environment, v. 235, no. 13, p. 143-150.

Lyman, W.J., Glazer, A.E., Ong, J.H., and Coons, S.F., 1987, An overview of sediment quality in the United States: U.S. Environmental Protection Agency, Monitoring and Data Support Division, Office of Water Regulations and Standards, contract no. 68-01-6951, task 20, 204 p.

Mahler, B.J., van Metre, P.C., Bashara, T.J., Wilson, J.T., and Johns, D.A., 2005, Parking lot sealcoat - an unrecognized source of urban polycyclic aromatic hydrocarbons: Environmental Science and Technology, v. 39, p. 5,560-5,566.

Mann, H.B., and Whitney, D.R., 1947, On a test of whether one of two random variables is stochastically larger than the other: Annals of Mathematical Statistics, v. 18, p. 50-60.

McNellis, R.P., Fallon, J.D., and Lee, K.E., 2001, Water-quality assessment of part of the Upper Mississippi River Basin, Minnesota and Wisconsin: Organochlorine compounds in streambed sediments and fish tissues, 1995-97: U.S. Geological Survey Water-Resources Investigations Report 00-4213, 10 p.
Minnesota Department of Natural Resources, 2006, Lake information report, accessed November 14, 2007, at http://www.dnr.state.mn.us/lakefind/showreport. html? downum $=48000200$.

Minnesota Department of Natural Resources, 2007, Technical definitions of wetland types in Minnesota, accessed November 14, 2007, at http://www.dnr.state.mn.us/wetlands/ types_technical.html.

Minnesota Department of Transportation, 1998, Historic roadside development structures on Minnesota trunk highways, accessed January 16, 2008, at http://www.dot.state.mn.us/ roadsides/historic/.

Minnesota Department of Transportation, 2002, TH169 Improvement Project: Minnesota Department of Transportation, Draft Environmental Impact Statement and Draft Section 4(f) Evaluation, 231 p.

Minnesota Office of the Revisor of Statutes, 2007, Minnesota rules for the Minnesota Pollution Control Agency: Chapter 7050, Waters of the State, accessed November 14, 2007, at https://www.revisor.leg.state.mn.us/rules/?id=7050.

Minnesota Pollution Control Agency, 1999, Legislative report on sources and effects of lead presented to the Committees on the Environment and Natural Resources, accessed July 11, 2007, at http://www.pca.state.mn.us/hot/legislaturel reports/1999/lead.pdf.

Minnesota Pollution Control Agency, 2007, Let's get the lead out!, accessed July 11, 2007, at http://www.pca.state.mn.us/ oea/reduce/sinkers.cfm.

Minnesota State Climatology Office, 2006, Minnesota's historical lake ice-out dates, accessed February 16, 2007, at http://climate.umn.edu/doc/ice_out/ice_out_historical.htm.

Mitton, G.B., and Payne, G.A., 1996, Quantity and quality of runoff from selected guttered and unguttered roadways in northeastern Ramsey County, Minnesota: U.S. Geological Survey Water-Resources Investigations Report 96-4284, $72 \mathrm{p}$.

Morlock, S.E., Nguyen, H.T., and Ross, J.H., 2002, Feasibility of acoustic doppler velocity meters for the production of discharge records from U.S. Geological Survey streamflowgaging stations: U.S. Geological Survey Water Resources Investigations Report 2001-4157, 59 p.

Patton, C.J., and Kryskalla. J.R., 2002, Methods of analysis by the U.S. Geological Survey National Water Quality Laboratory - evaluation of alkaline persulfate digestion as an alternative to Kjeldahl digestion for determination of total and dissolved nitrogen and phosphorus in water: U.S. Geological Survey Water-Resources Investigations Report 2003-4174, 33 p. 
Patton, C.J., and Truitt, E.P., 2000, Methods of analysis by the U.S. Geological Survey National Water Quality Laboratory-determination of ammonium plus organic nitrogen by a Kjeldahl digestion method and an automated photometric finish that includes digest cleanup by gas diffusion: U.S. Geological Survey Open-File Report 2000-170, 31 p.

Rantz, S.E., and others, 1982, Measurements and computation of streamflow, volumes 1 and 2: U.S. Geological Survey Water-Supply Paper 2175, 631 p.

Runkel, R.L., Crawford, C.G., and Cohn, T.A., 2004, Load Estimator (LOADEST): A FORTRAN program for estimating constituent loads in streams and rivers: U.S. Geological Survey Techniques and Methods, book 4, chap. A5, 69 p.

Shelton, L.R., and Capel, P.D., 1994, Guidelines for collecting and processing samples of stream bed sediment for analysis of trace elements and organic contaminants for the National Water-Quality Assessment Program: U.S. Geological Survey Open-File Report 94-458, 20 p.

Short, T.M., Black, J.A., and Birge, W.J., 1991, Ecology of a saline stream - community responses to spatial gradients of environmental conditions: Hydrobiologia, v. 226, p. $167-178$.

Stark, J.R., Andrews, W.J., Fallon, J.D., Fong, A.L., Goldstein, R.M., Hanson, P.E., Kroening, S.E., and Lee, K.E., 1996, Water-quality assessment of part of the Upper Mississippi River Basin, Minnesota and Wisconsin, environmental setting and study design: U.S. Geological Survey WaterResources Investigations Report 96-4098, 62 p.

Stoica, A., Katzenellenbogen, B.S., and Martin, M.B., 2000, Activation of estrogen receptor by the heavy metal cadmium: Molecular Endocrinology, v. 14, no. 4, p. 545-553.

Taggart, J.E., 2002, Analytical methods for chemical analysis of geologic and other materials, U.S. Geological Survey: U.S. Geological Survey Open-File Report 2002-223, 20 p.

Telisman, S., Cvitkovic, P., Jurasovic, J., Pizent, A., Gavella, M., and Rocic, B., 2000, Semen quality and reproductive endocrine function in relation to biomarkers of lead, cadmium, zinc, and copper in men: Environmental Health Perspectives, v. 108, p. 45-53.

Trotta, L.C., and Cowdery, T.F., 1998, Ground water resources of the Mille Lacs Lake area, east-central Minnesota: U.S. Geological Survey Water-Resources Investigations Report 97-4116, $29 \mathrm{p}$.

U.S. Department of Commerce, 2004, Climatological data annual summary, Minnesota, 2003: National Oceanic and Atmospheric Administration, v. 109, no. 13, 29 p.
U.S. Department of Commerce, 2005, Climatological data annual summary, Minnesota, 2004: National Oceanic and Atmospheric Administration, v. 110, no. 13, 29 p.

U.S. Department of Commerce, 2006, Climatological data annual summary, Minnesota, 2005: National Oceanic and Atmospheric Administration, v. 111, no. 13, 35 p.

U.S. Department of Commerce, 2007, Climatological data annual summary, Minnesota, 2006, National Oceanic and Atmospheric Administration, v. 112, no. 13, 36 p.

U.S. Department of Health and Human Services, 2007, ToxFAQs part of Agency for Toxic Substances and Disease Registry, accessed July 11, 2007, at http://www.atsdr.cdc. gov/toxfaq.html.

U.S. Environmental Protection Agency, 1990, Appendix B to Chapter 2-general program guidance of the water quality standards handbook, 1983: U.S. Environmental Protection Agency, Office of Water Regulations and Standards, Office of Wetlands Protection, accessed March 29, 2007, at http:// www.epa.gov/owow/wetlands/regs/quality.html $\# 4.2 \% 20$ Numeric\%20Criteria.

U.S. Environmental Protection Agency, 2007, Nutrient criteria technical guidance manual for wetlands: U.S. Environmental Protection Agency, EPA-822-R-07-004, accessed November 20, 2007, at http://www.epa.gov/waterscience/ criteria/nutrient/guidance/.

U.S. National Library of Medicine, 2006, Hazardous Substances Data Bank part of TOXNET Toxicology Data Network, accessed February 8, 2007, at http://toxnet.nlm. nih.gov/cgi-bin/sis/htmlgen?HSDB.

U.S. Geological Survey, variously dated, National field manual for the collection of water-quality data: U.S. Geological Survey Techniques of Water-Resources Investigations, book 9, chaps. A1-A9, available online at http://pubs.water.usgs. gov/twri9A.

Verschueren, Karel, 1983, Handbook of environmental data on organic chemicals: New York, Van Nostrand Reinhold, $1,310 \mathrm{p}$.

Wagner, R.J., Mattraw, H.C., Ritz, G.F., and Smith, B.A., 2000, Guidelines and standard procedures for continuous water-quality monitors - site selection, field operation calibration, record computation, and reporting: U.S. Geological Survey Water-Resources Investigations Report 2000-4252, $53 \mathrm{p}$.

Wetzel, R.G., 2001, Limnology—lake and river ecosystems: San Diego, Academic Press, 1,006 p.

Wilcoxon, F., 1945, Individual comparisons by ranking methods: Biometrics Bulletin, v. 1, p. 80-83. 


\section{Tables 2 and 3}



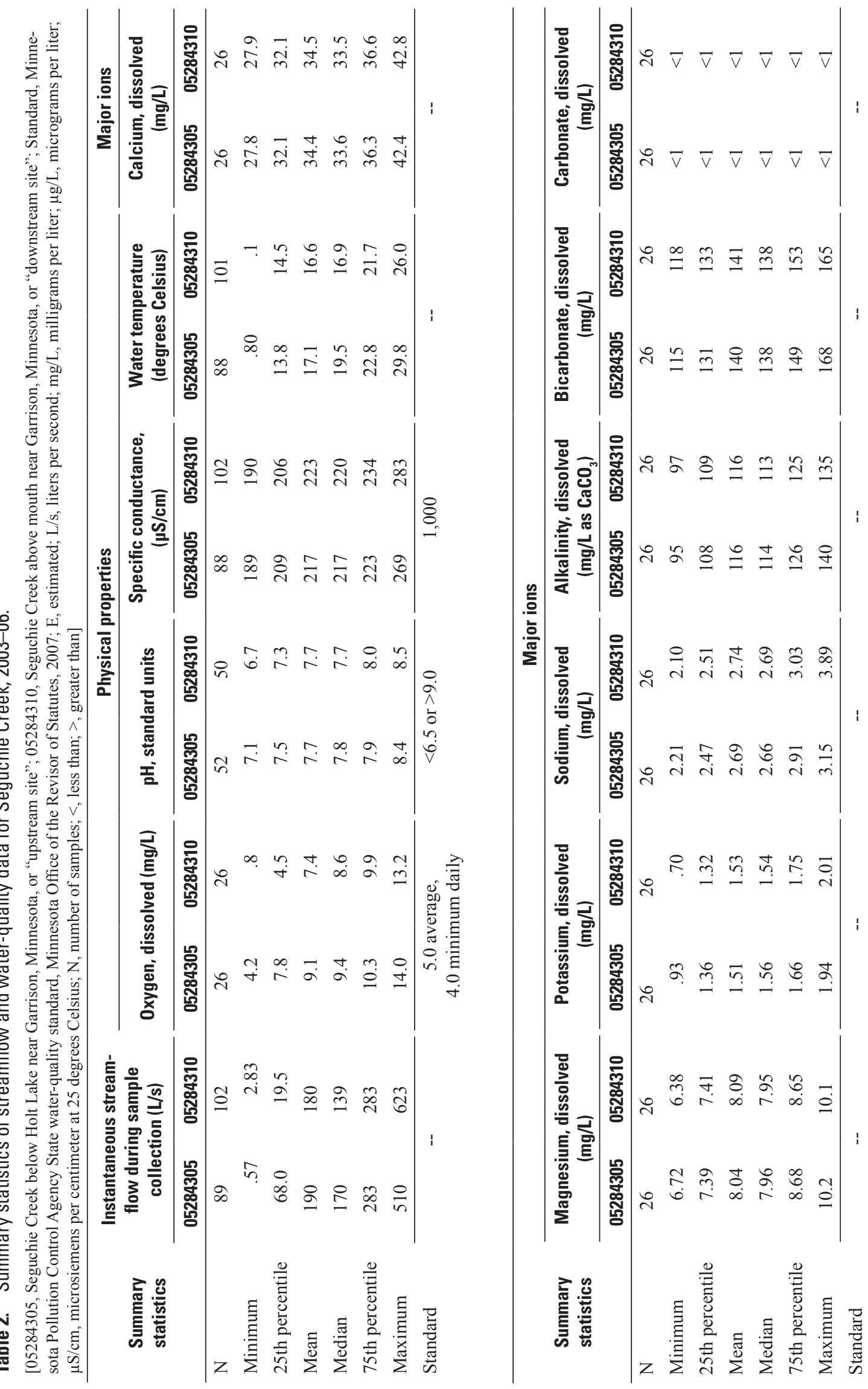

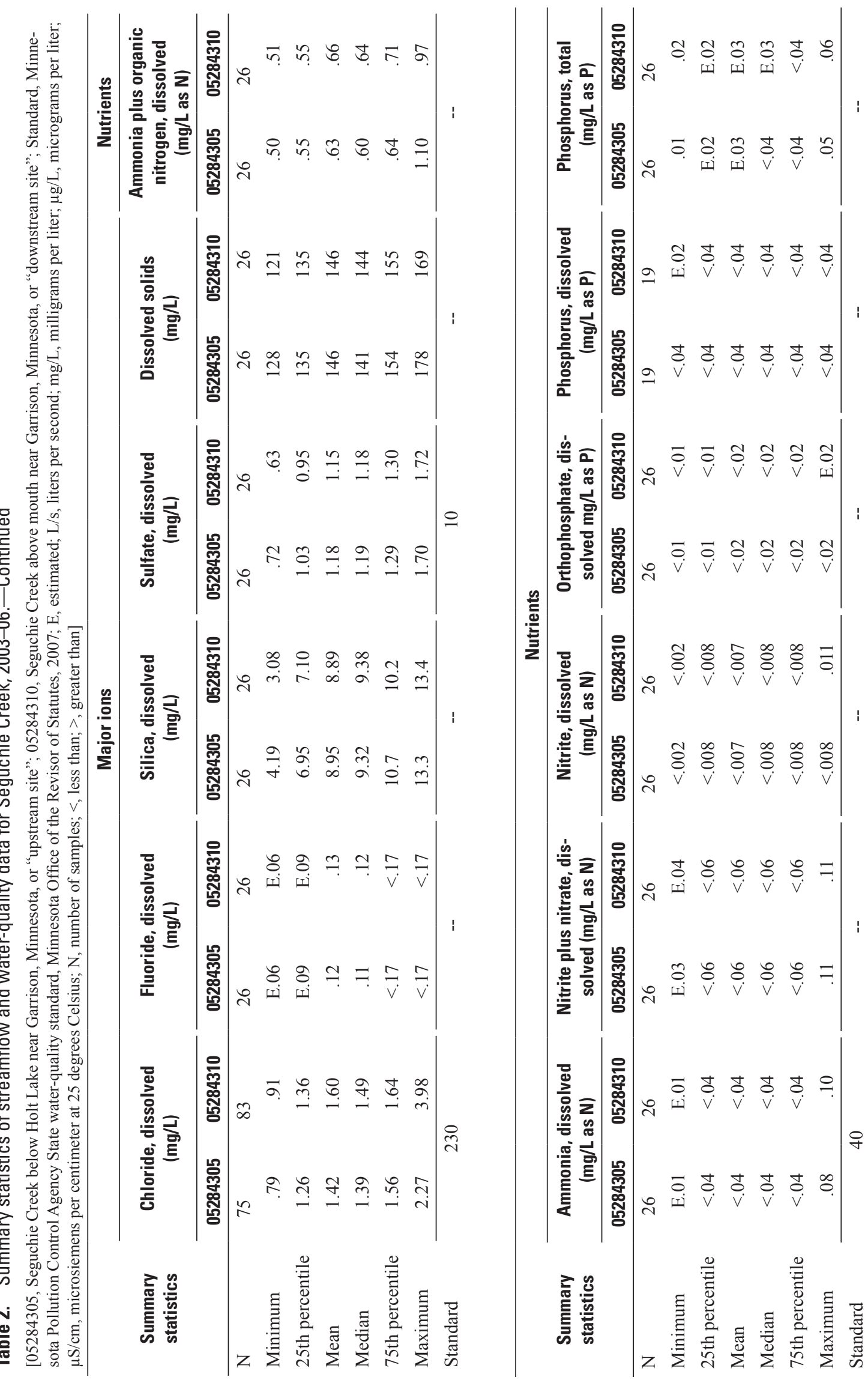


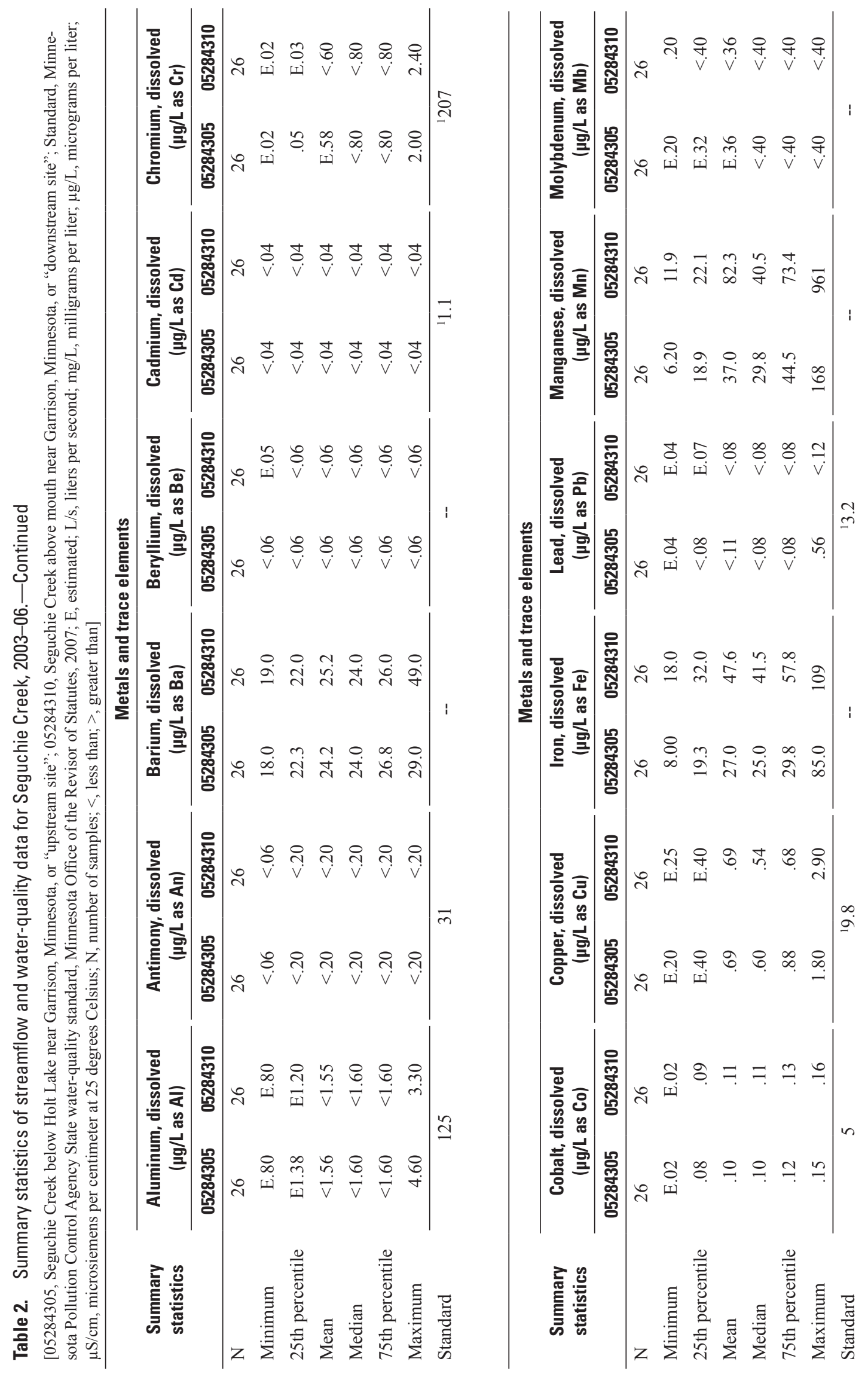




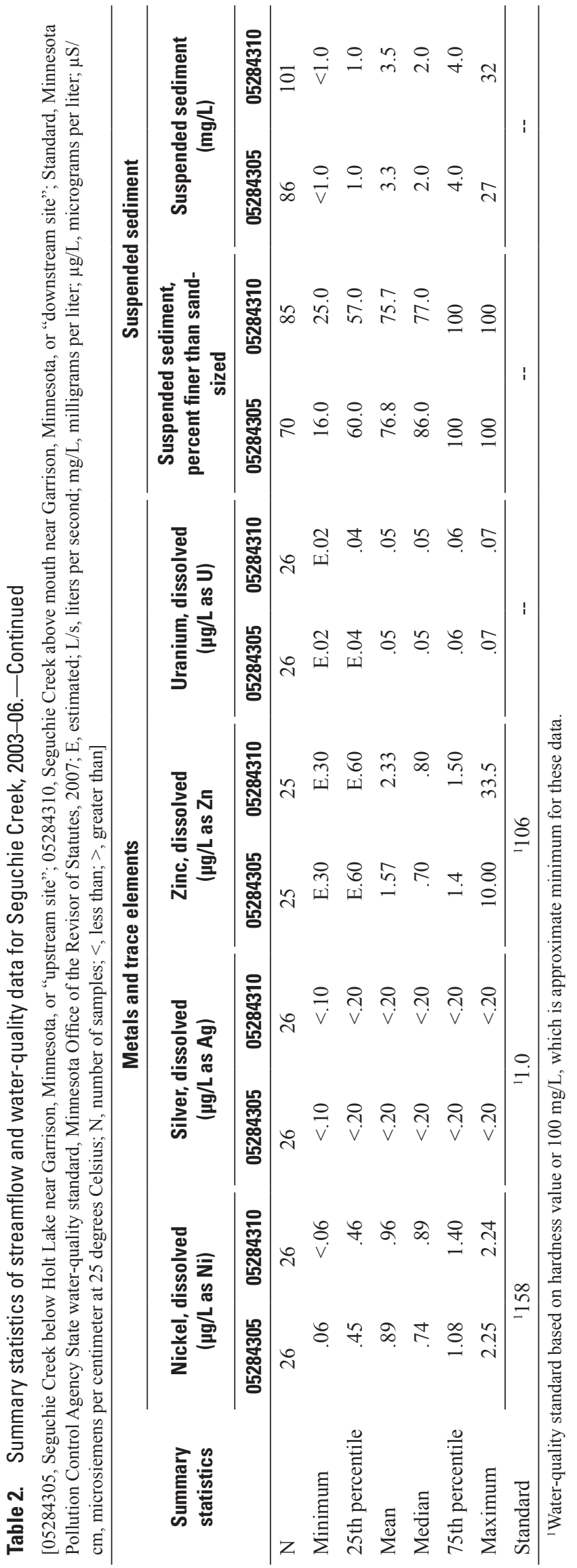



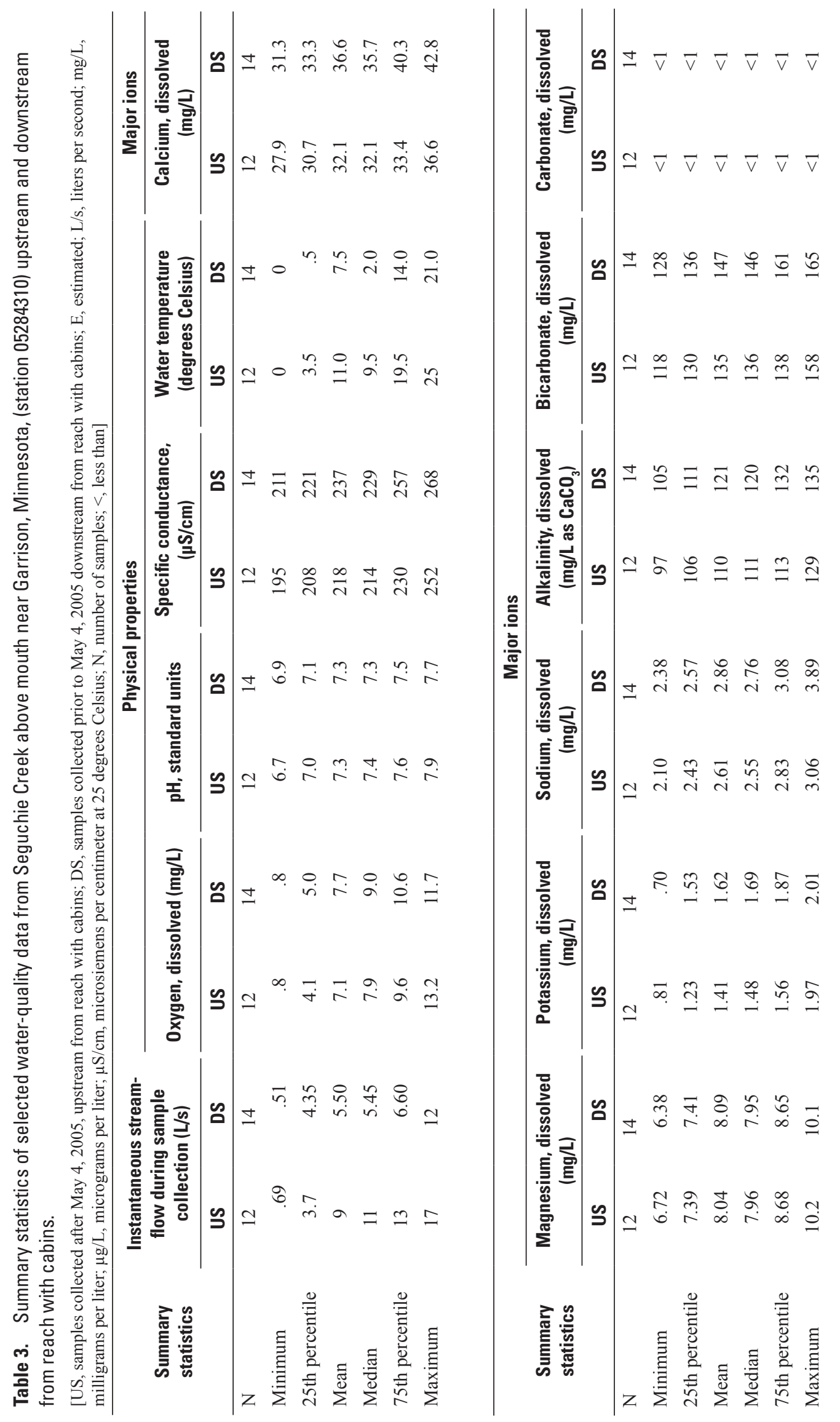

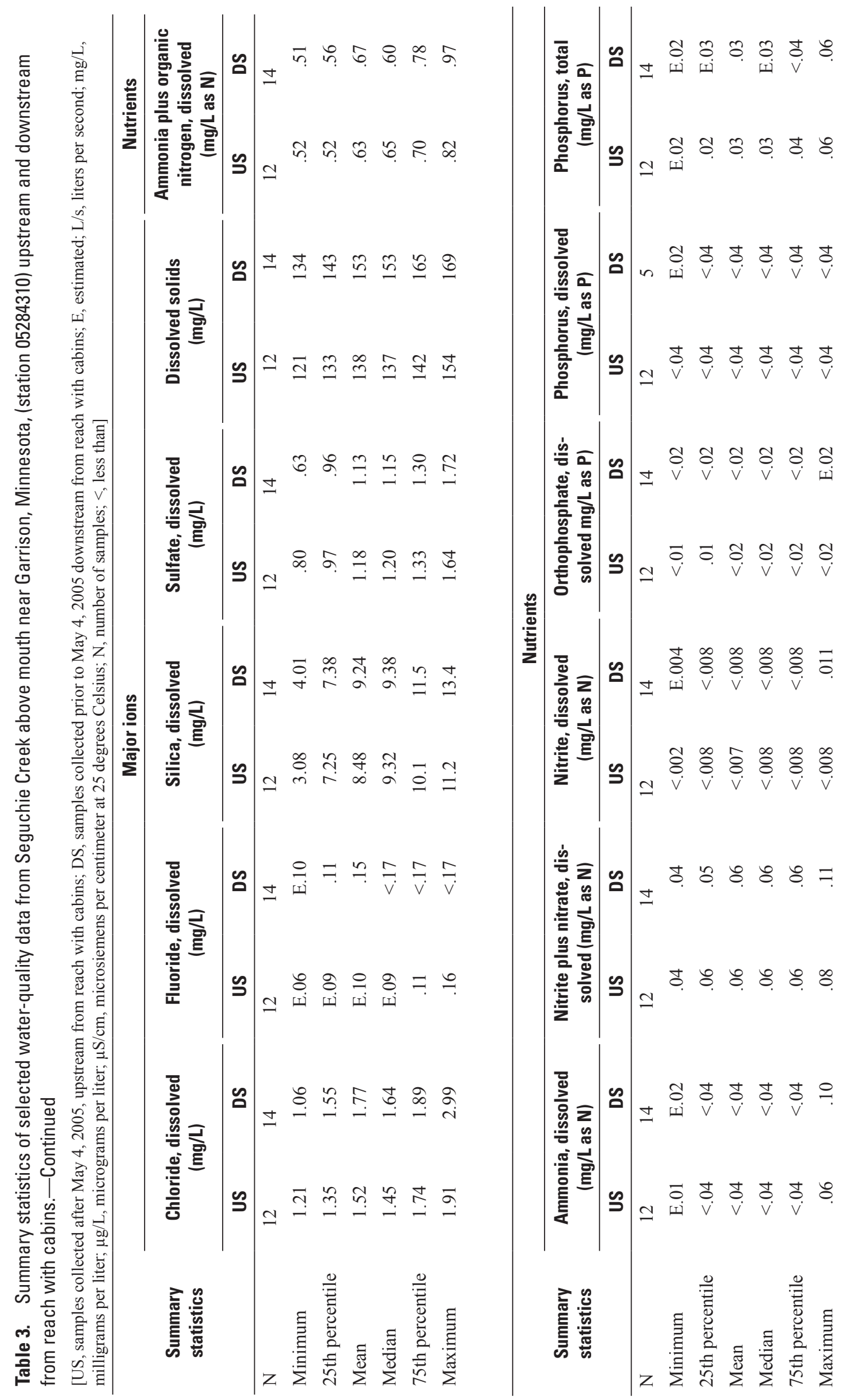


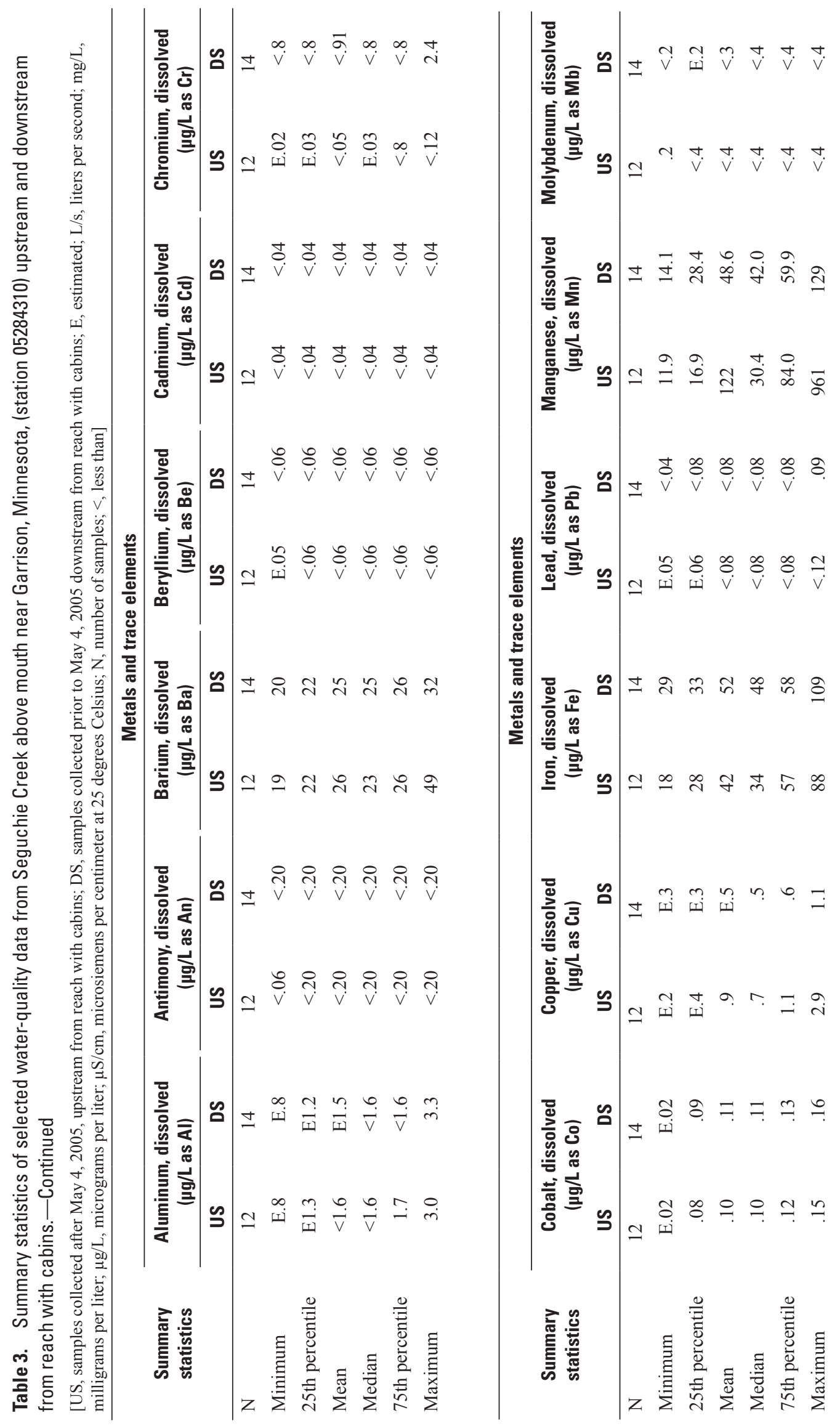




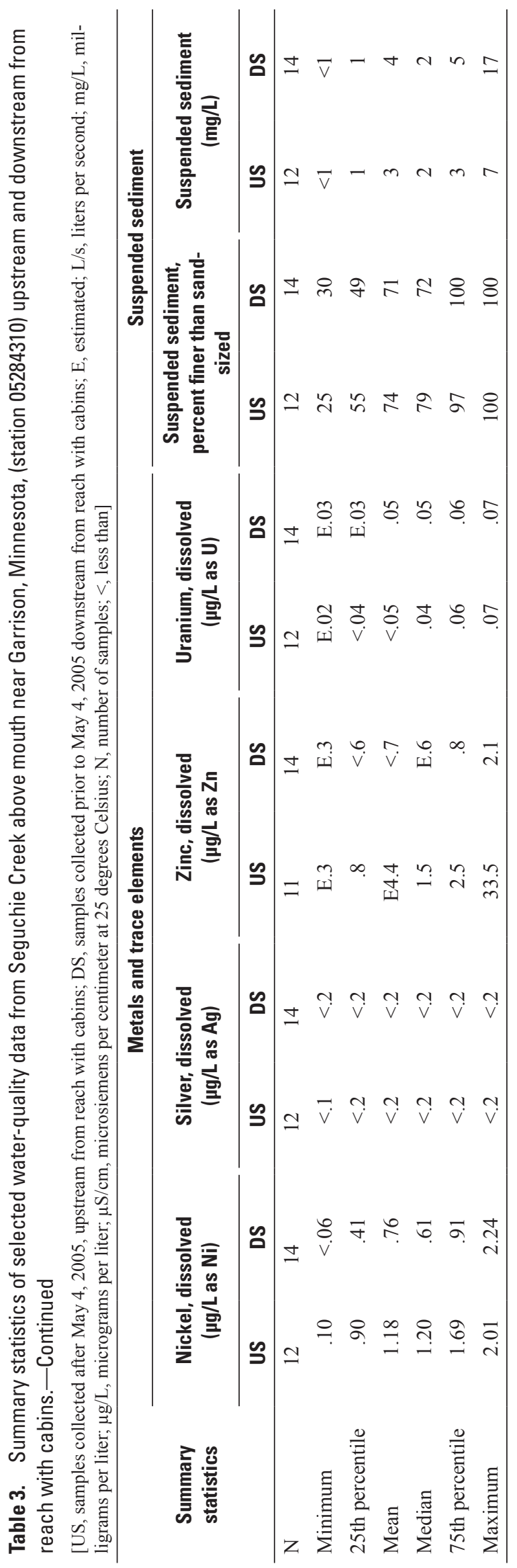


Publishing support provided by:

Rolla Publishing Service Center

For additional information concerning this publication, contact:

Director, USGS Minnesota Water Science Center

2280 Woodale Drive, Mounds View, MN (763) 783-3100

Or visit the Minnesota Water Science Center Web Site at: http://mn.water.usgs.gov 



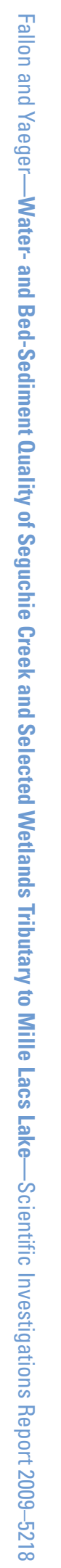

